\title{
Males, Mature Larvae, and Nests of Ropalidia plebeja, a Nearly Solitary Paper Wasp Endemic to Sulawesi (Insecta: Hymenoptera: Vespidae), with Taxonomic Notes on the $R$. plebeja Group
}

\author{
Jun-ichi Kojima ${ }^{1}$, Sri Hartini' ${ }^{2}$, Sih Kahono ${ }^{2}$, \\ Naoyuki Fujiyama ${ }^{3}$ and Haruo Katakura ${ }^{3}$ \\ ${ }^{1}$ Natural History Laboratory, Faculty of Science, \\ Ibaraki University, Mito, 310-8512 Japan \\ ${ }^{2}$ Balitbang Zoologi, Puslitbang Biologi, LIPI, Jl. Raya Bogor Km 46, \\ P.O. Box 25, Cibinong 16911, Bogor, Indonesia \\ ${ }^{3}$ Graduate School of Science, Hokkaido University, Sapporo, 060-0810 Japan
}

(Received 29 March 2001; Accepted 10 November 2001)

\begin{abstract}
The morphologies of the male, mature larva, and nest of Ropalidia plebeja (Saussure, 1862, non 1863) are described for the first time. A nest of $R$. celebensis Van der Vecht, 1941 and the mature larvae and details of nest structure of $R$. rufoplagiata (Cameron, 1905) are also described for the first time. Taxonomic notes and a key to species of the $R$. plebeja group, which includes $R$. plebeja, $R$. celebensis, $R$. rufoplagiata, $R$. andamanensis Das and Gupta, 1989, R. turneri Richards, 1978, and R. cristata Kojima, 1989, are provided. New synonymies proposed are $R$. gravelyi Dover and Rao, 1922 and $R$. rufoplagiata nursei Van der Vecht, 1941, both under $R$. rufoplagiata. The colony populations of $R$. plebeja suggest that this species probably has a nearly solitary life habit. Character states supporting the monophyly of the $R$. plebeja species group, and those linking it to the $R$. gracilis (Smith, 1859) species group, are examined in detail.
\end{abstract}

Key Words: Vespidae, Polistinae, Ropalidia plebeja, R. plebeja group, Sulawesi, male, larva, nest, nearly solitary paper wasp.

\section{Introduction}

The social wasp genus Ropalidia Guérin-Méneville, 1831, consisting of about 180 extant species (Kojima and Carpenter 1997), is one of the largest genera among the social wasps. Richards (1978) recognized six subgenera in the genus Ropalidia; on the other hand, Kojima (1997) showed that Richards' definition of the subgenera was supported on no robust grounds and proposed to abandon subgeneric concepts in the genus. Although relationships among species and/or species groups are still under analysis (Kojima and Carpenter, unpublished), several species groups that are defined by robust characters have been proposed (e.g., Kojima 2001). One of those species groups is the $R$. plebeja group (so far referred to as the " $R$. rufoplagiata group"; see Kojima 2001), which includes the following six species: $R$. an- 
damanensis Das and Gupta, 1989, $R$. celebensis Van der Vecht, $1941, R$. cristata Kojima, 1989, R. plebeja (Saussure, 1862), R. rufoplagiata (Cameron, 1905), and $R$. turneri Richards, 1978. The synapomorphic character for this species group is that the first metasomal tergum is barely petiolate basally but abruptly swollen dorsally at the posterior end of the basal slit. Several characters in the morphologies of the males, larvae, and nests could be candidates for syapomorphies of this species group, but relevant information for this species group is still very limited. Specifically, the larval morphology and details of male morphology and nest structure of $R$. rufoplagiata are not yet reported; available specimens of $R$. plebeja are only the female from Gorontalo, North Sulawesi, noted in the original description (Saussure 1862) and a female later recorded from Lake Paso, central Sulawesi (Van der Vecht 1962: 33); no collection record has been added to the original records of $R$. celebensis (the holotype female and a female noted as a variation; Van der Vecht 1941 ) and $R$. andamanensis (only the holotype female; Das and Gupta 1989).

In our research expeditions to South Sulawesi, Lombok, and Sumbawa Islands in Indonesia made in October and November, 2000, we collected nests of R. plebeja, $R$. celebensis, and $R$. rufoplagiata, which provided us material to describe, for the first time, details of nest structure of the three species, the larval morphology of $R$. plebeja and $R$. rufoplagiata, and the male of $R$. plebeja. Taxonomic notes and a key to the species of the $R$. plebeja group are also provided. All the nomenclatural changes proposed in this paper are to be attributed to JK, who is solely responsible for them.

\section{Materials and Methods}

Nests of Ropalidia plebeja were collected in South Sulawesi at Puncak Lakawan (seven nests; Erotic Mountain Lookout, $03^{\circ} 29^{\prime} \mathrm{S} 119^{\circ} 48^{\prime} \mathrm{E}$, alt. $500 \mathrm{~m}$ ), Bambapuang, Enrekang, on 28 October 2000, and at Battang (one nest; $02^{\circ} 57^{\prime} \mathrm{S} 120^{\circ} 07^{\prime} \mathrm{E}$, alt. $260 \mathrm{~m}$ ), Warateluwanua, Luwu, on 29 October 2000 . A nest of $R$. celebensis was collected by Dr. N. Tsurusaki at Puncak Palopo $\left(02^{\circ} 58^{\prime} \mathrm{S} 120^{\circ} 05^{\prime} \mathrm{E}\right.$, alt. $\left.800 \mathrm{~m}\right)$, Tojambu, Battang, Warateluwanua, Luwu, South Sulawesi, on 30 October 2000. Nests of $R$. rufoplagiata were collected at Pusuk (two nests; Monkey Forest, $08^{\circ} 28^{\prime} \mathrm{S}$ $116^{\circ} 05^{\prime} \mathrm{E}$, alt. $290 \mathrm{~m}$ ), Gunungsari, Lombok Barat, Lombok Island, on 3 November 2000 , and Batudulang (one nest; $08^{\circ} 35^{\prime} \mathrm{S} 117^{\circ} 17^{\prime} \mathrm{E}$, alt. $800 \mathrm{~m}$ ), Batulanteh, Sumbawa Besar, Sumbawa Island (a new record from this island), on 10 November 2000.

All adult wasps available for the present study were those collected with these nests and those emerging from the nests (Table 1). All of the adult wasps collected with the nests were females except for a male of $R$. plebeja, and the females (except for $R$. celebensis; pinned and dried after collection) were kept in $70 \%$ ethanol until dissection to check for presence/absence of sperm in the spermathecae and the condition of the ovaries, and then they were pinned. After the composition of immature individuals in the nests was recorded, the larvae were removed and mature ( $=5$ th instar) larvae were preserved in $70 \%$ ethanol for later observation. Then those nests that had pupae were kept in small plastic boxes at room temperature, and emerging adults were collected and pinned.

The adult morphology except for the male genitalia was observed on pinned specimens under a stereoscopic dissecting microscope with an ocular micrometer 
and a drawing apparatus. The male terminal sterna and genitalia were dissected out, briefly cleared in $\mathrm{KOH}$, and mounted on glass slides in glycerin for observation under both a stereoscopic dissecting microscope and a compound microscope. Terminology of the male genitalia follows Kojima (1999a).

Coloration of mature larvae was observed on specimens in $70 \%$ ethanol under a stereoscopic dissecting microscope. One mature larva of $R$. plebeja and four mature larvae of $R$. rufoplagiata were cleared in hot $\mathrm{KOH}$ and heavily stained with acid fuchsin. They were dissected and mounted on glass slides in Canada balsam to observe microscopic structures under a compound microscope. The terminology of the larval morphology follows Kojima (1998).

The nest characters, including measurements of various parts taken with vernier calipers to the nearest $0.5 \mathrm{~mm}$ (comb size) or $0.05 \mathrm{~mm}$ (other measurements), were examined after the nests had been air-dried. The terminology of nest characters follows Wenzel (1998). Wasps of the four genera of the tribe Ropalidiini make a hole at the base of a cell to pull out the meconium egested by a post-feeding larva; in Ropalidia and Parapolybia the hole is closed by adults' oral secretion to form a semitransparent "window" (Kojima 1996).

For each taxon, pagination for the original citation is followed by the sex(es) and the citation of the original locality; then major taxonomic references are listed. The complete list of references and the depositories of the name-bearing type specimens are available in the catalog of Kojima and Carpenter (1997) and on a web site for the up-dated version (http://www.sci.ibaraki.ac.jp/ jkrte/wasp/ ropa/top.html).

Three females, one male, and two nests of $R$. plebeja and four females of $R$. rufoplagiata are deposited in the Museum Zoologicum Bogoriense, Bogor, and the remaining specimens are deposited in the Natural History Laboratory, Ibaraki University, Mito (IUNH). In addition to these specimens collected in Indonesia, a female and male of $R$. rufoplagiata collected in Bangalore, India, and provided by Dr. R. Gadagkar (deposited in the IUNH) were used for comparison. The specimens of $R$. cristata and $R$. turneri used for comparison are those housed in the IUNH, the Australian National Insect Collection of CSIRO (Canberra), and the Nationaal Natuurhistorisch Museum (Leiden).

\section{Descriptions \\ Ropalidia plebeja (Saussure, 1862)}

Icaria plebeja Saussure, 1862: 138, female, "Gorontalo" [Sulawesi].

Ropalidia plebeja: Van der Vecht 1941: 111, 169 [redescription of the type, inadvertently referring to it as the "holotype"; this should be regarded as the designation of the lectotype (International Code of Zoological Nomenclature Art. 74.6; International Commission on Zoological Nomenclature 1999), while Kojima and Achterberg (1997) overlooked Van der Vecht's (1941) statement when they designated the same specimen as the "lectotype" of Icaria plebeja Saussure, 1862, non 1863]; 1962: 33.

\section{Adult female}

The original description by Saussure (1862) and Van der Vecht's (1941) re- 
description of the lectotype do not refer to some of the characters that are important from a phylogenetic point of view. The following description of the adult female is based on our 14 specimens listed in Table 1 . There are discrepancies in several characters, especially in morphometric characters, between the states in our specimens and those mentioned for the lectotype by Van der Vecht (1941); the states given in Van der Vecht (1941) are given in brackets. JK briefly examined the lectotype deposited in the Nationaal Natuurhistorisch Museum in Leiden when he visited there in 1996, and found errors in some measurements given in Van der Vecht (1941); for example, the Dutch author mentioned, "Posterior ocelli only about $1 / 2$ times as far from the eyes as from each other" (p. 169), but JK determined that the posterior ocelli are about 1.25 times as far from the eyes as from each other-the latter value agrees with those for our material.

Body length (head + mesosoma + first two metasomal segments) $8-9.5 \mathrm{~mm}$; forewing length $7-8 \mathrm{~mm}$.

Head in frontal view (Fig. 1) about 1.1 [1.08] times as wide as high; in dorsal view (Fig. 3) about twice [2.05] as wide as long, with lateral margins behind eyes slightly convex and distinctly narrowed posteriorly, shallowly emarginate posteriorly, and about as wide as mesosoma including tegulae ["scarcely wider than the thorax (39:37)"]. Distance between posterior ocelli nearly 3 times [nearly 3 times] as long as their diameter, about 0.75 [0.67] times as long as distance between posterior ocellus and inner eye margin, and much longer than distance between posterior and anterior ocelli; area between ocelli slightly raised. Vertex behind ocelli nearly flat (Fig. 2), not sloping down to occipital carina. Inner eye margins converging ventrally; distance between them at vertex about 1.25 [about 1.35 ] times as wide as that at clypeus. Clypeus weakly convex, pointed below, transverse, about 1.3 times as wide (excluding lateral lobes) as high (measured from bottom of dorsal emargination to apex) ["somewhat wider than long (17:15)"; but it is unclear which parts Van der Vecht (1941) measured]. Mandible normal, not twisted. Gena in profile (Fig. 2) weakly widening ventrally to level of mid-height of eye, then slightly narrowing further ventrally, about 0.8 (range $0.71-0.88$ ) times as wide [about as wide] as eye; occipital carina complete, fine, smoothly and weakly curved. Malar space short. Antenna as in Fig. 4; scape slightly curved, slightly more than 3.5 [about 3.5] times as long (excluding radicle) as wide; flagellum weakly thickened apically to tenth article; tenth article little more than 1.5 times as wide as third article; third article about 2.8 [less than three] times as long as its own apical width, about 1.4 times as long as fourth and fifth articles combined; each of fourth to 11th articles wider than long; terminal article nearly bulletshaped, about as long as its basal width.

Mesosoma rather thick. Pronotum in dorsal view with anterior margin weakly rounded; lateral sides slightly concave and weakly diverging posteriorly; pronotal carina complete, raised into low lamella, barely sinuate at humeral angles (Fig. 6). Scutum weakly convex, about as long as wide. Disc of scutellum trapezoid, weakly convex, with median part nearly flat and lateral margins truncate. Disc of metanotum nearly flat, with fine lateral marginal carinae, and with posterior margin broadly rounded. Propodeum with wide, median, oval concavity (Fig. 7); posterior face in profile (Fig. 6) steeply sloping down, slightly concave in ventral half, weakly angled at mid-height of propodeum, and then nearly vertical; propodeal orifice rounded above, about twice as long as wide; propodeal valvula small (in 

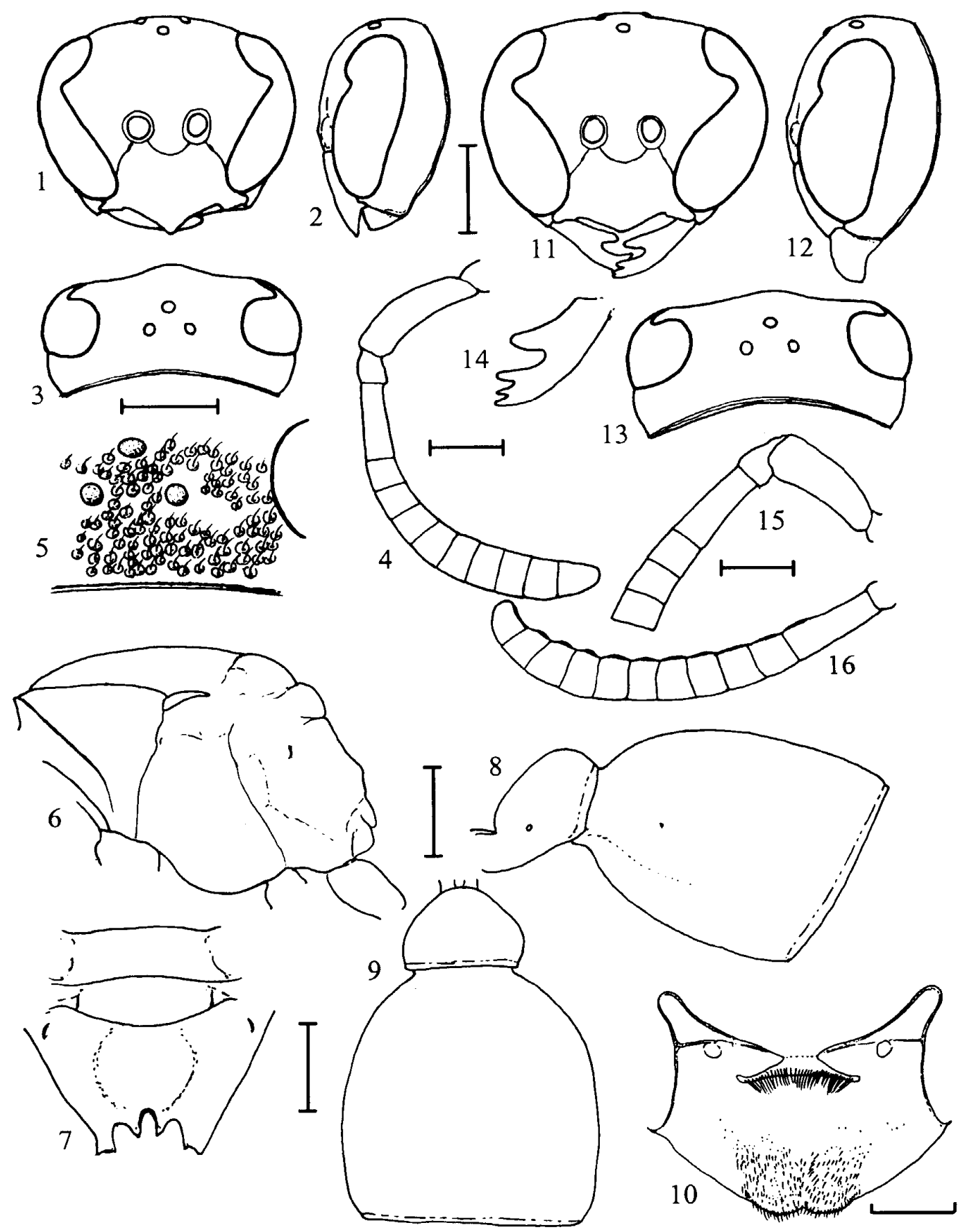

Figs 1-16. Ropalidia plebeja. 1-10, female; 11-16, male. 1-3, 11-13, head (1, 11, frontal view; 2 , 12 , lateral view; 3,13 , dorsal view); 4, 15-16, right antenna; 5, ocellar area; 6 , mesosoma, lateral view; 7, scutellum, metanotum, and propodeum, posterodorsal view; 8-9, first two metasomal segments (8, lateral view; 9 , dorsal view); 10 , terminal sternum; 14, left mandible. Scale lines: $1-3,6-9,11-13,1 \mathrm{~mm} ; 4-5,10,14-16,0.5 \mathrm{~mm}$. 
profile most part of propodeal tooth visible), with broadly rounded triangular outline and marginal carina at base.

First metasomal segment short, about as long (measured in profile from posterodorsal corner to posterior margin of basal slit corresponding to mesosomal suspensory ligament) as maximum width of tergum (Figs 8-9); tergum in dorsal view (Fig. 9) strongly widened posteriorly after very short, basal, parallel-sided part, then weakly constricted near apical margin; maximum width of posterior widened part nearly 3.5 times as great as width of basal, parallel-sided part; in profile (Fig. 8) abruptly swollen dorsally at posterior end of basal slit, then dorsal surface weakly rounded, soon arising in nearly straight line, and curved down to posterior margin in posterior one-third; posterior lamella narrow, barely depressed ["depressed"; but Van der Vecht's (1941) fig. 50 (p. 166) shows no depression]; in ventral view, ventral margins of tergum weakly approaching each other before posterior divergence; sternum emarginate posteriorly. Second metasomal segment about 1.1 times as long as wide, 1.2 times as long as high, about twice [about twice] as wide as maximum width of first tergum; suture between tergum and sternum barely visible; posterior lamella narrow, weakly depressed; posterior margin of articulation of tergum sharply truncate laterally, followed by rugose punctures in short "neck". Terminal sternum as in Fig. 10; pair of small, unpigmented, weakly sclerotized circles present anterolaterally (sometimes absent).

Body covered with appressed tomentum and dense, suberect, silvery setae; setae longer on apical part of clypeus than on other body parts. Clypeus with remote, shallow punctures; frons with dense punctures, their interspaces nearly linear (oval area beside each antennal socket unpunctured); vertex less densely punctured, interspaces between punctures narrower than their diameters; punctures on gena sparser, their interspaces wider than their diameters. Pronotum, scutum, metapleura, and lateral sides of propodeum with dense punctures as on frons; punctures on scutellum and metanotum slightly larger, with interspaces slightly wider than those on scutum; posterior margin of metanotum unpunctured and polished; median concavity of propodeum with fine, transverse striae; dorsolateral surface of propodeum with distinct (sometimes weak), oblique striae. First metasomal tergum unpunctured on anterior face, with ill-defined punctures preapically; punctures on second metasomal tergum relatively small, their interspaces wider than their diameters; punctures on second sternum larger and shallower than those on tergum.

Head black; clypeus yellow, with black central spot (often large) and area above this black spot reddish-brown; spot at inner orbit and spot between antennal sockets (usually separated into paired small spots) yellow; spot filling dorsal emargination of clypeus, ill-defined large spot between antennal sockets and anterior ocellus (often limited to ventral half), ill-defined spot above yellow spot at inner orbit, central spot behind posterior ocelli (usually absent), and most of gena (sometimes reduced to posterior band narrowing ventrally) reddish-brown; mandible pale orange in apical half, brown basally, and with basal yellow spot. Antenna brown to dark reddish-brown, but yellowish beneath; third article often dark brown above. Mesosoma black; pronotum reddish-brown, except black pronotal collar and wide yellow band along carina; large scrobal spot (sometimes reduced in size), disc of scutellum, anterior half of metanotum (sometimes black), pair of illdefined spots on posterolateral corners of propodeum (sometimes absent), and 
propodeal teeth reddish-brown; posterior half of metanotum and propodeal valvula yellow. First metasomal segment reddish-brown, with wide, pre-apical, yellow band on tergum; second metasomal segment dark reddish-brown (sometimes nearly black), with pre-apical yellow band (sometimes interrupted medially on sternum); third to sixth metasomal segments reddish-brown. Legs reddish-brown; coxae black, with yellow marking on fore coxa; trochanters black basally; femora black dorsoapically. Wings hyaline, with subapical blackish cloud as in $R$. celebensis (see Fig. 58); stigma yellowish-orange; veins brown.

\section{Adult male}

The following description is based on the three males listed in Table 1.

Body length (head + mesosoma + first two metasomal segments) $8.5-9.5 \mathrm{~mm}$; forewing length 7-9 $\mathrm{mm}$.

Structure as in female except for following characters: head in frontal view (Fig. 11) relatively wider than in female, about 1.25 times as wide as high; distance from posterior ocellus to inner eye margin proportionally longer, about 1.5 times as long as distance between posterior ocelli (Fig. 13); inner eye margins more strongly convergent ventrally; distance between them at vertex about 1.6 times as wide as that at clypeus (Fig. 11); clypeus (Fig. 11) smaller, much less produced below, with rounded apex, about 1.35 times as wide as high; eye slightly more strongly swollen; gena in profile (Fig. 12) slightly narrower proportionally, about 0.72 (range $0.69-0.77 ; n=3$ ) times as wide as eye. Mandible (Fig. 14) with deep, wide emargination between dorsalmost and second teeth. Antenna as in Figs 15-16; scape shorter than in female, about 2.5 times as long as wide; third article about 2.35 times as long as its apical width; fourth to 12th articles each wider (excluding tyloid) than long; sixth to 11th articles all nearly of same width; terminal segment slightly curved, with rounded apex, about 1.35 times as long as its basal width; apical one-third of third article and fourth to terminal articles with longitudinal, ridge-like tyloids.

Terminal sterna and genitalia as in Figs 17-22. Parameral spine lacking hairs; Parameral Spine Index of Charnley (1973): (length of projection beyond lobe)/(total length of paramere and spine) $\times 100=20$. Volsella as in most Ropalidia species (see Kojima 1999a). Penis valves about 0.85 times as long as basal apodeme; in profile (Fig. 21) apical part curved ventrally; proximal margin (Fig. 22) with weak teeth.

Coloration generally as in female, but most of reddish-brown markings reduced or absent. Head black, with following parts yellow: small spot above each antennal socket, spot at inner orbit, large lateral triangular spots on clypeus, and dorsal part and small basal spot on mandible; teeth of mandible reddish-brown; antenna dark brown above, yellowish-brown beneath. Pronotum reddish-brown, with black spot at each posterodorsal corner, and yellow band along carina; scutellum with narrow black band along anterior margin; metanotum black anteriorly, yellow posteriorly; marking pattern of other parts of mesosoma as in female. Second metasomal segment black, with yellow apical band. Legs: coxae black, with yellow marking apically; trochanters black, but yellow apically; fore and mid femora reddish-brown, but basal two-thirds black beneath; hind femur largely black; all tarsi brown to pale brown. Male collected with Nest R-09 with reduced black spots on pronotum; mandibles largely yellow, with black basal spot; black band on scutellum wider than in other males; and reddish-brown parts of legs more extensive. 

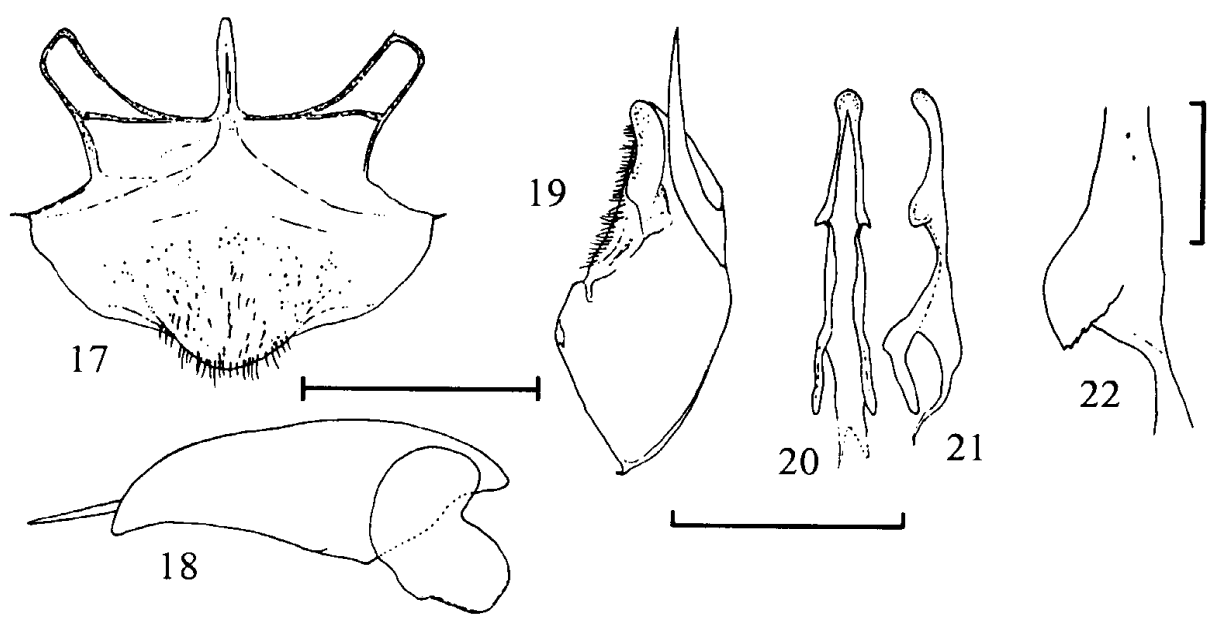

Figs 17-22. Male terminal sterna (17) and genitalia (18-22) of Ropalidia plebeja. 18, phallic capsule, lateral view; 19, inner aspect of paramere with volsella and digitus; 20-21, aedeagus (20, ventral view; 21 , lateral view); 22 , proximal part of penis valve, ventral view. Scale lines: $17-21,1 \mathrm{~mm} ; 22,0.1 \mathrm{~mm}$.

\section{Mature larva}

Cranial width $1.6-1.7 \mathrm{~mm}(\mathrm{n}=2)$.

Cranium dark grayish brown (Fig. 23); gena less strongly pigmented, pale brown; center of antenna, wide median band on frontal surface running from posterior margin to level of anterior tentorial pits, and parietal band barely pigmented. Mouthparts, including labrum, unpigmented; conical papillae on labrum, apical part of maxilla, ventral half of prementum, and ventral part of postmentum pale-brown to brown; maxillary and labial palpi, galea, basal sclerotized ring of maxilla, and spot ventrolateral to maxilla dark brown. Body unpigmented, but areas around leg-bud plates dark brown.

Cranium in frontal view (Fig. 24) suboval, widest slightly below level of antennae, about 1.3 times as wide as high; in profile (Fig. 25) smoothly curved anteriorly, deeply emarginate posteriorly; integument with scattered minute punctures, each bearing minute seta. Ecdysial sulcus ill-defined. Outer half of parietal band weakly reticulate. Antenna small, separated from anterior tentorial pit by distance about twice diameter of antenna, with three minute sensilla (two of them located very close to each other). Clypeus nearly half as wide as maximum width of cranium. Labrum (Fig. 26) not narrowed at junction with clypeus, slightly narrower than ventral width of clypeus, with 20 small punctures bearing minute setae and about 20 small, conical papillae medioventrally; ventral margin with sparse, minute spicules. Palate (Fig. 27) with about 10 conical papillae medially, several minute punctures dorsally, and spicules along ventral margin and on lateral sides (arranged in rows). Mandibles (Fig. 28) short, not crossed when closed, mono-dentate, weakly curved apically, and gradually attenuate into sharp apex in apical half; outer surface with several minute spicules. Maxilla (Fig. 29) weakly swollen laterally, with sclerotized basal ring; upper surface covered with dense spicules arranged in rows; ventral surface with scattered small punctures, each bearing minute seta; maxillary palpus (Fig. 30) with apex weakly produced in ventral half, and with four apical sensilla (two located on produced half of palpus); galea deeply 

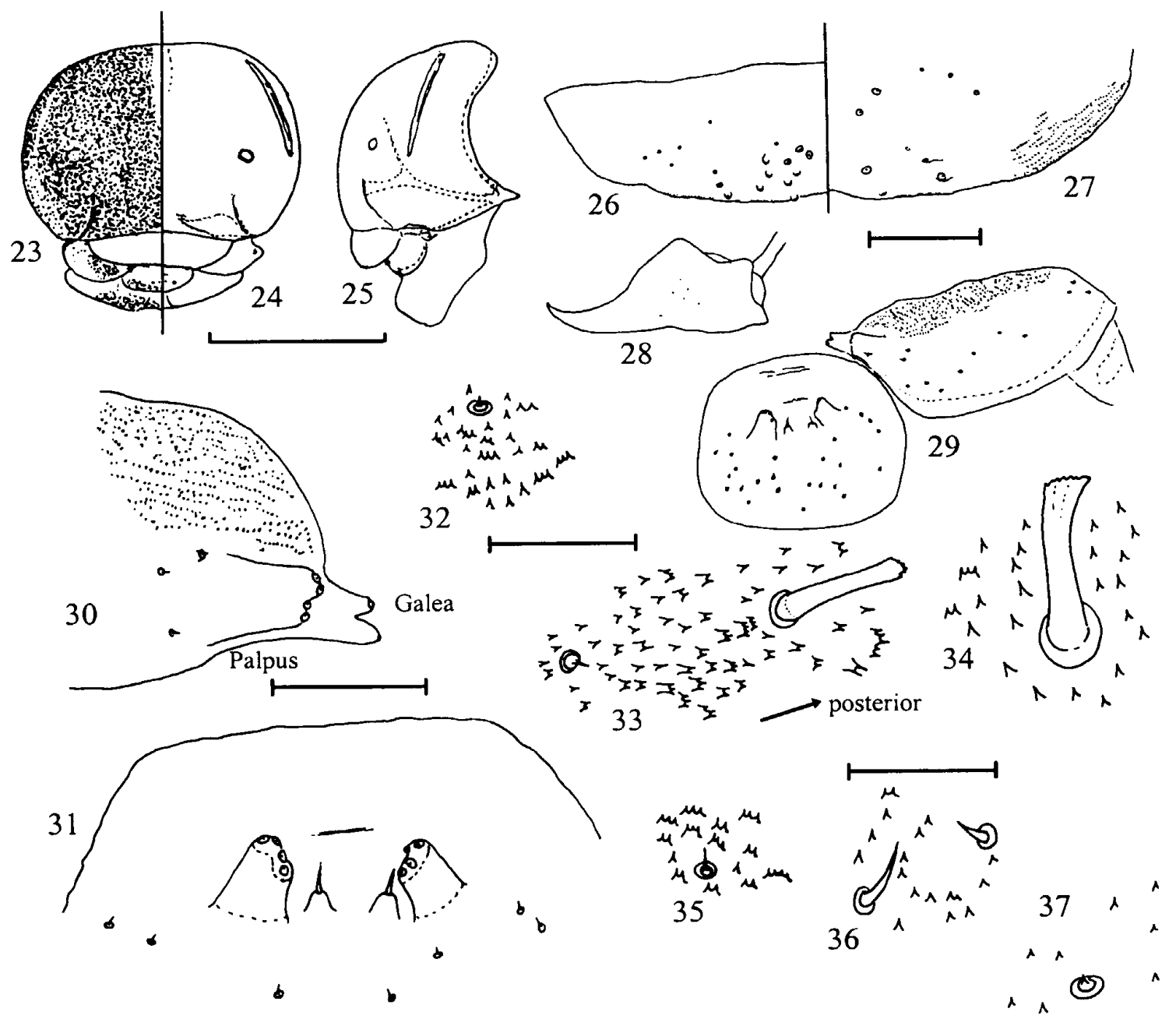

Figs 23-37. Mature larva of Ropalidia plebeja. 23-24, head, frontal view (23, marking pattern; 24 , external structure); 25 , head, lateral view; 26, labrum; 27 , palate; 28 , left mandible; 29 , left maxilla and prementum; 30, apical part of right maxilla; 31, dorsal part of prementum; 32-37, setae and spicules on body integument (32, venter of second thoracic segment; 33 , venter of third thoracic segment; 34, venter of first abdominal segment; 35, dorsum of first thoracic segment; 36 , dorsum of first abdominal segment; 37 , dorsum of eighth abdominal segment). Scale lines: 23-25, $1 \mathrm{~mm} ; 26-29,0.2 \mathrm{~mm} ; 30-31,0.1 \mathrm{~mm} ; 32-37,0.05 \mathrm{~mm}$.

bi-lobed, each lobe with one apical sensillum. Prementum (Fig. 29) rounded quadrate, with about 25 scattered, minute setae in area below level of labial palpi, and lacking any spicules; labial palpus (Fig. 31) similar to maxillary palpus, with four apical sensilla (two located on slightly produced outer half of palpus); paired setae behind palpi long, with strongly raised sockets; area between palpi without spicules. Postmentum not well developed, weakly emarginate ventrally, with scattered minute setae dorsally, and lacking spicules.

Spiracular atrium bare; first spiracle about twice as wide in diameter as remaining ones. Setae and spicules on body integument as follows: anterior half of venter of first thoracic segment (T1) with scattered, minute setae, and without spicules, area between leg-bud plates with sparse, minute, apically pointed 
spicules; T2 venter (Fig. 32) with scattered, minute setae and covered with dense, small spicules, sometimes contiguous to form 3- to 5-dentate ridges; T3 venter (Fig. 33) with spicules same as on T2 venter; setae in anterior part of T3 venter scattered and short, those in posterior part thick, long, and minutely dentate apically; spicules on venters of first to tenth abdominal segments (A1-A10) becoming sparser and less frequently contiguous on posterior segments; apical part of A10 venter without spicules; setae on A1 venter (Fig. 34) as on posterior part of T3 venter, but thicker and longer; setae on A2-10 venters like those on T2 venter; dorsal lobes bare; setae on dorsums of all body segments scattered, minute, but most setae on A1 dorsum (Fig. 36) somewhat stronger; spicules on T1-3 dorsums (Fig. 35) dense and most of them contiguous; spicules on abdominal dorsums (Fig. 37) becoming sparser and less contiguous toward posterior segments; posterior half of A9 dorsum and most of A10 dorsum lacking spicules.

\section{Nest}

All of the nests collected at Puncak Lakawan (Nests R-05 to R-10, R-12, and Loc05) were constructed under two "parasols" (diameter about $1.5 \mathrm{~m}$, and 2-2.5 $\mathrm{m}$ in roof height) made of a wooden frame and hemp-palm fibers; the nests were attached either to the wooden frames or to hemp-palm fibers. The nest collected at Battang (Nest R-11) was constructed under the eaves of a small house about $2 \mathrm{~m}$ above the ground. All the nests except Nest R-12 consisted of a single comb; Nest R12 (Fig. 45) had two combs made close to each other (about $5 \mathrm{~mm}$ apart) in a shallow small hole on a frame board. The color of a comb (or its cell walls) was in general uniformly pale brown to grayish brown, but sometimes the cell wall had rather wide, well-defined stripes of different colors, as in Nest Loc-05 (Fig. 46); close observation under a stereoscopic dissecting microscope revealed that the uniform coloration of the comb was due to a mixture of nest materials of different origins rather than to a uniform origin of the material.

Other characters are as follows: nest material consisting of short chips of plant fiber mixed with large amount of oral secretion; pedicel for first cell (= primary pedicel) with thin central core mainly made of chips of plant fiber, thickly coated with oral secretion; Nest R-09 with two additional pedicels connecting pre-existing cell bases and substrate, these pedicels made mainly of oral secretion, but with small amount of plant fiber chips mixed into terminal parts of both. Cells arranged regularly, barely divergent toward open ends; free margins of peripheral cells rounded in basal 2-3 mm, but weakly angled to form hexagonal cell outlines in farther extending cells; mean length and side-to-side diameter of pupal cells $10.6 \mathrm{~mm}$ $(\mathrm{n}=10$, range $9.1-13.3 \mathrm{~mm})$ and $3.55 \mathrm{~mm}(\mathrm{n}=10$, range $3.3-3.7 \mathrm{~mm})$, respectively; nonpupal cells with "windows" usually shorter than pupal cells, with length ranging from $3.8 \mathrm{~mm}$ to $9.5 \mathrm{~mm}$, and side-to-side diameter from 2.8 to $3.8 \mathrm{~mm}$. Cocoon cap brown to dark brown, nearly flat at level slightly (about $1 \mathrm{~mm}$ ) inside rim of cell or at level of rim of cell, or domed and strongly (about $1.5 \mathrm{~mm}$ ) produced beyond rim of cell; often with blots of chips of plant fibers.

In addition to these nests, we collected 25 abandoned nests from the same "parasols"; judging from their shapes and cell sizes, they could belong to $R$. plebeja. The size of these nests ranged from four to 28 cells; 21 nests (cell number from four to 28) had single pedicels, three nests (each with 8, 9 and 11 cells) had two pedicels each, and one nest (with 28 cells) had three pedicels; all the secondary 

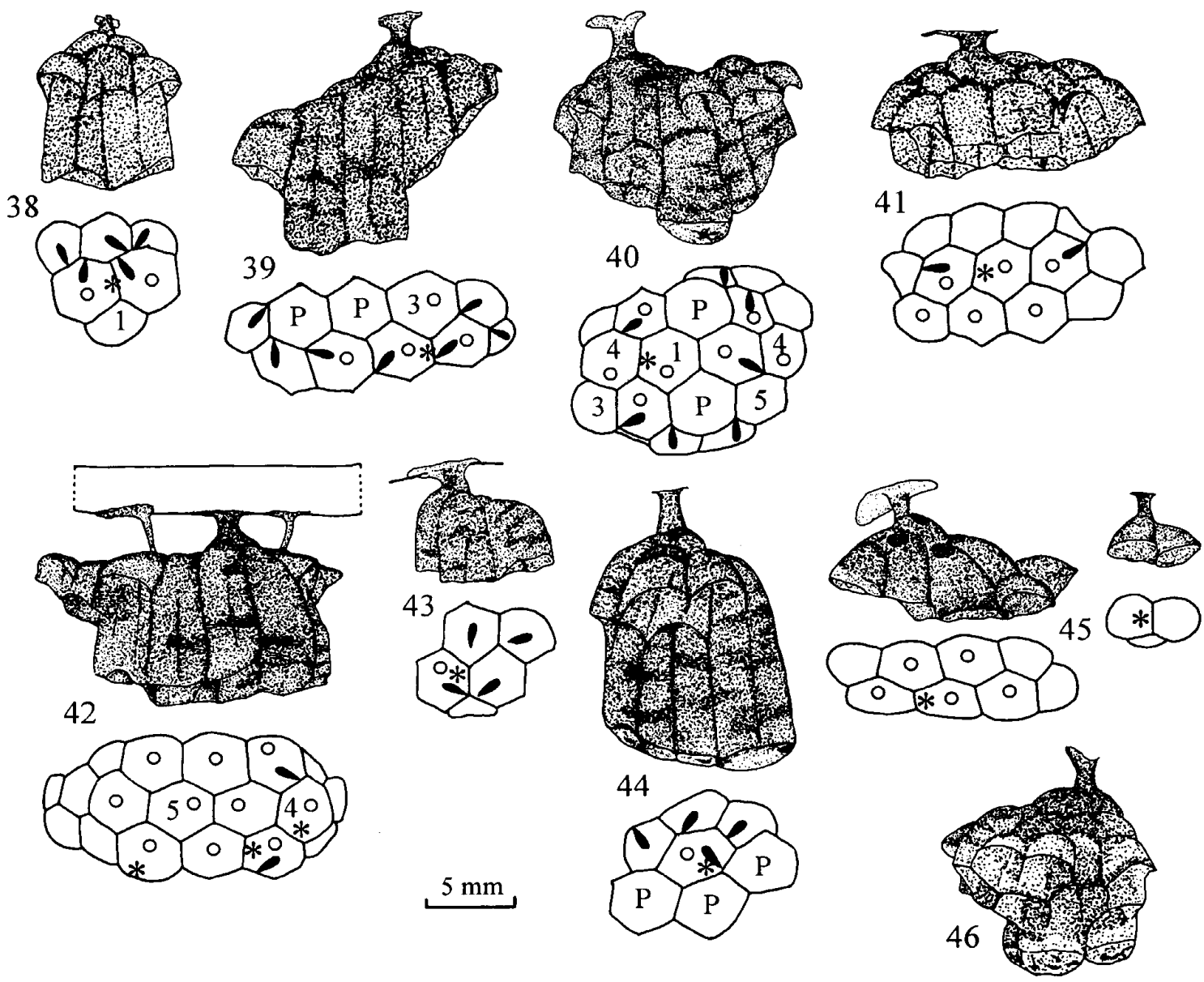

Figs 38-46. Nests of Ropalidia plebeja, lateral view and view from cell opening (showing outlines of cell margins, deposition of immature stages, position of pedicel, and presence of "window" at bottom of cell). Solid tear-drop marks, eggs; numerals, instar stages of larvae; "P", pupa, cell bottom with "window"; open circle, "window" at bottom of non-pupal cell; asterisks (*), positions of pedicels. 38, Nest R-05; 39, R-06; 40, R-07; 41, R-08; 42, R-09; 43, R-10; 44, R-11; 45, R-12, consisting of two combs; 46 , Loc-05, view from cell opening not given.

pedicels were made mainly of oral secretion.

\section{Colony composition}

The sizes of the eight active nests and a dead pupae-containing nest (Nest Loc05 ) ranged from five to 18 cells (mean $\pm S E M=11.3 \pm 1.6$ ); all of them had at least one cell with a "window" (Figs 38-45). When we collected the nests, the wasps were inactive on the nests and no foraging activities were performed, possibly because the weather was cloudy with occasional showers; therefore, the number of wasps away from the nests for foraging might have been zero. Each nest was attended by a maximum of two females (Table 2). Dissections of attending females showed that each nest had a single inseminated female with more or less developed ovaries with mature oocytes (Fig. 47), and when two females attended the nests, one of them was uninseminated and had undeveloped ovaries with filamentous ovarioles. Exceptions were Nest R-09, which contained eggs and larvae, but was attended 
Jun-ichi Kojima et al.

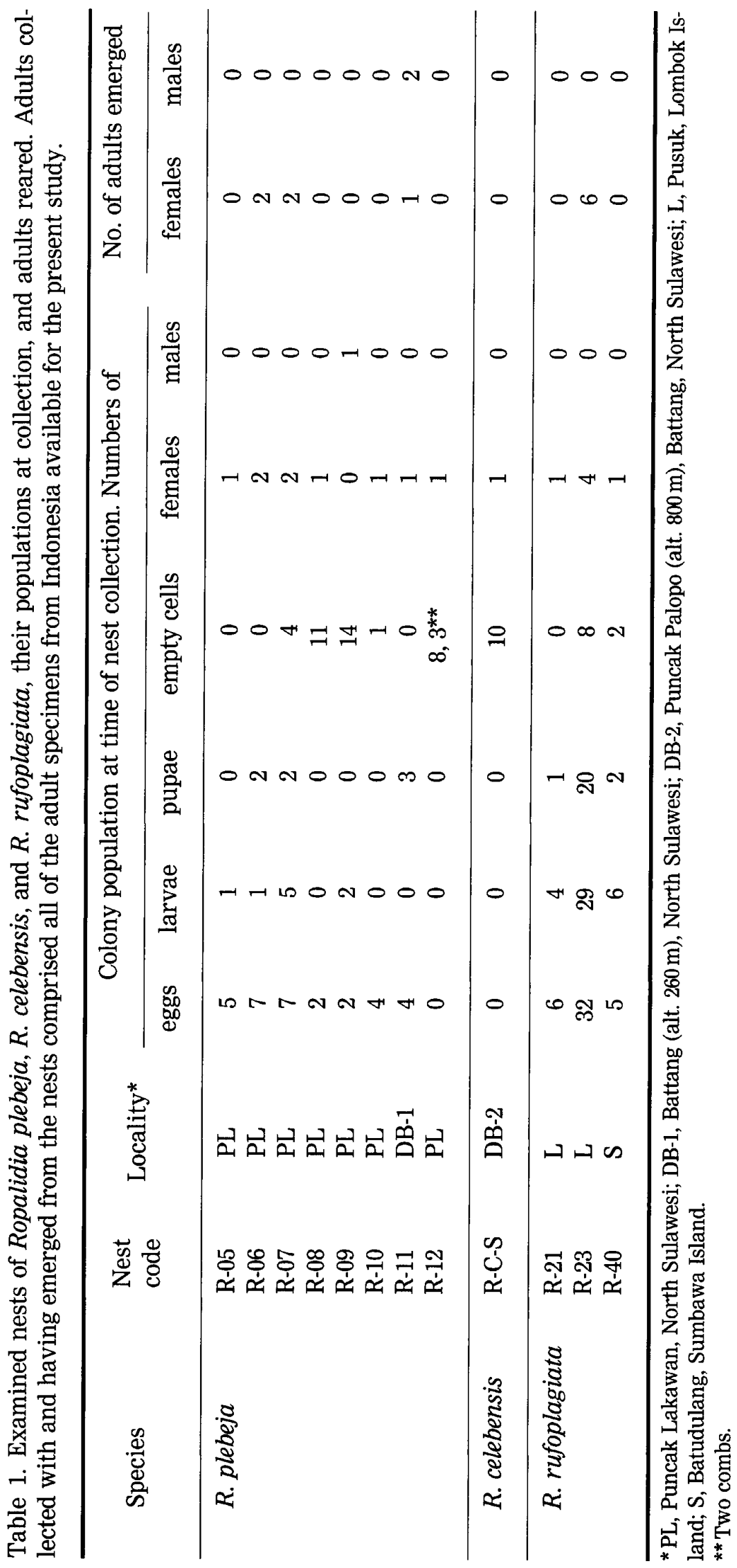


Taxonomy of the Ropalidia plebeja group

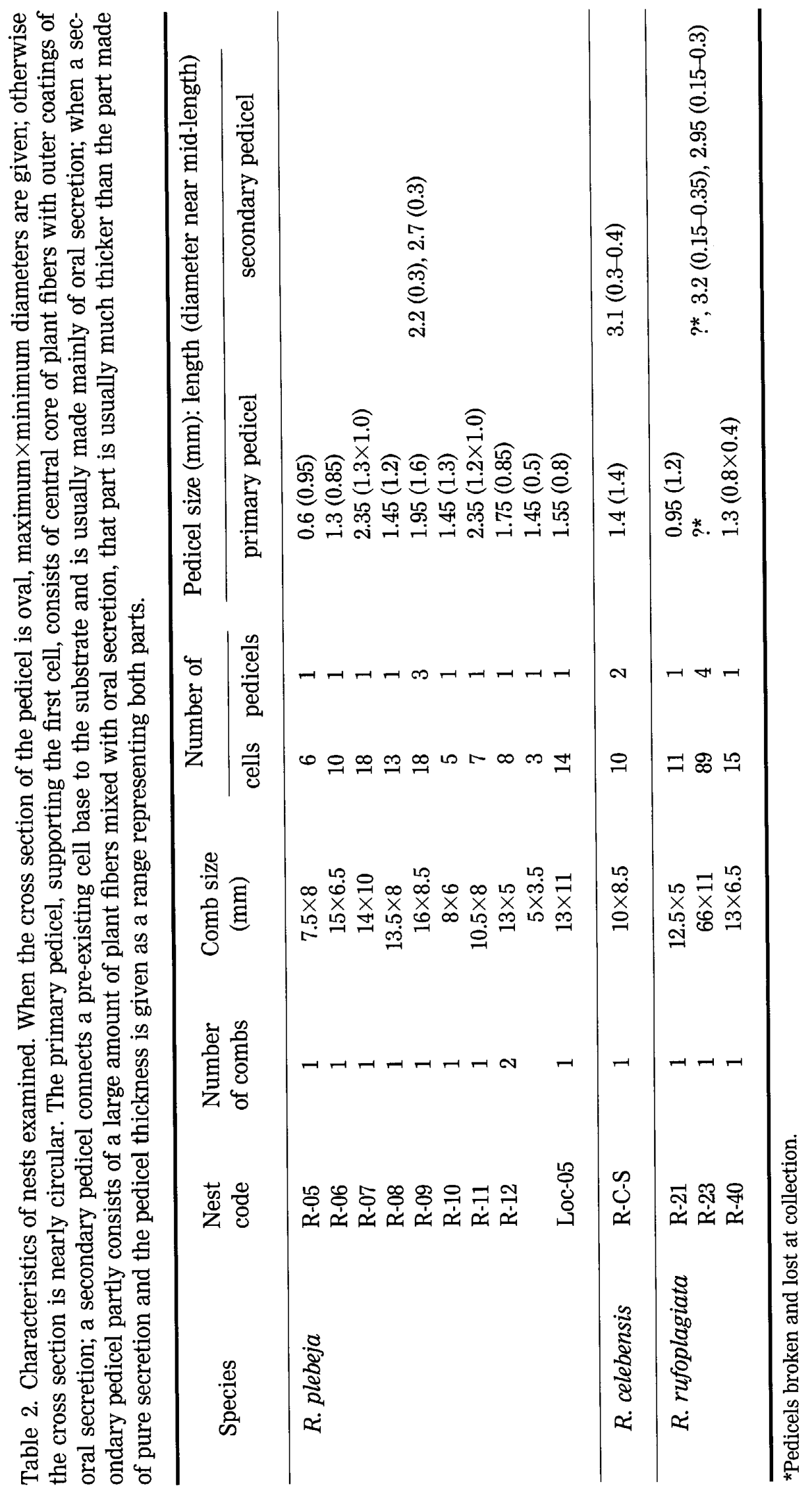



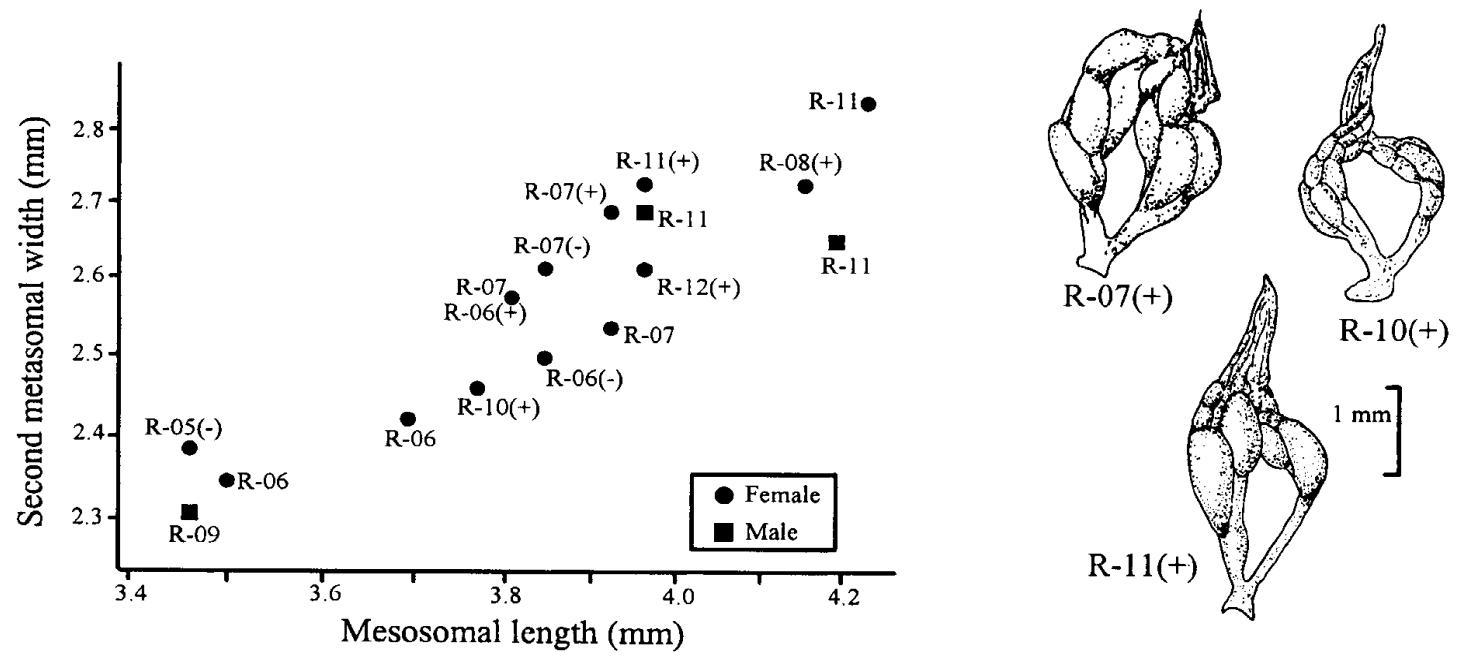

Fig. 47. Relationships of mesosomal length and second metasomal width, and ovary conditions in Ropalidia plebeja. The nest code for each individual is given; "+" and "-" in parentheses indicates presence or absence of sperm in spermathecae, respectively. Individuals without "+" or "-" are those that emerged from the nests after collection. Uninseminated females had undeveloped ovaries; inseminated females, such as those of Nests R-07 and R-11, had more or less developed ovaries with mature oocytes, but that of Nest R-10 did not have mature oocytes and the inseminated female of Nest R-12 had an undeveloped ovary with filamentous ovarioles.

only by a male; Nest R-05, which had eggs and a larva, while the attending female was uninseminated, had undeveloped ovaries, and seemed to be young judging from her rather soft cuticle; and Nest R-12, the attending female of which was inseminated but her ovaries were undeveloped. The inseminated females in Nest R07 and R-10 had their forewings apically worn, while other females had fresh wings. The body size rather largely varied between colonies, but was not distinctly different among individuals in a given colony (Fig. 47).

Mean cell number for the eight active nests was $11.0 \pm 1.8$ (SEM). An adult male emerged from Nest R-11 on 6 November, eight days after nest collection, suggesting that the number of the fewest cells at male emergence in this species could be less than ten.

All of the abandoned nests but three (consisting of four, four, and ten cells, respectively) had cells with "windows"; mean cell number for the nests with "windows" was 13.2 \pm 1.5 (SEM); the smallest nest with "windows" had four cells, two of which had them.

\section{Ropalidia celebensis Van der Vecht, 1941}

Ropalidia celebensis Van der Vecht, 1941: 111, 170, female, "S. Celebes: ... Bantoe Batoe District, Latimodjong Mts".

\section{Adult female}

The following description is based on the female listed in Table 1. The state 
given in the original description by Van der Vecht (1941) is given in brackets when there is a discrepancy.

Body length (head +mesosoma + first two metasomal segments) 8.5 [9] $\mathrm{mm}$; forewing length $7.2 \mathrm{~mm}$.

Structure, including punctation and setal condition, similar to that in $R$. plebeja, but differing as follows: distance between posterior ocelli (Fig. 48) about 0.75 [0.5] times as long as distance from posterior ocellus to inner eye margin and about 3 times [less than twice] as wide as their diameter; gena proportionally wider than in R. plebeja, in profile (Fig. 49) slightly narrower than eye; terminal antennal article (Fig. 51) distinctly longer than its basal width. Propodeum in profile (Fig. 54) with posterior face barely concave dorsally (see Fig. 6 for $R$. plebeja); lateral sides with several oblique striae dorsally [without transverse striae on sides of posterior face]. First metasomal tergum about as long as its maximum width, latter nearly 3 times as greater than width of short, basal, parallel-sided part; in profile (Fig. 55) less strongly swollen posteriorly and more strongly curved down near posterior margin than in $R$. plebeja (see Fig. 8); in dorsal view (Fig. 56) barely narrowed apically. Second metasomal segment (Figs 55-56) slightly longer than wide; "neck" of tergum behind articulation with short longitudinal striae laterally (Fig. 57).

Head black; mandible dark reddish-brown, with yellow spot basally [entirely ferruginous]; clypeus with large lateral, triangular, yellow spots; paired small spots between antennal sockets and small spot at inner orbit dull yellow [inter-antennal shield, except for brownish median line, and short line at inner orbit yellow]. Antenna dark reddish-brown; scape and third to terminal articles yellowishorange beneath. Mesosoma black; pronotum reddish-brown dorsally, with wide yellow band along pronotal carina, this band having short branches along posterior margin [pronotum and propleura, except for small dark spot in front of tegulae, yellow]; tegula yellow, with outer semitransparent brownish spot [tegula yellow]; scutellum black, with large, lateral, dark reddish-brown spots [brownish, with two large yellow spots at anterior angles]; metanotum black, with wide, yellow apical band [entirely yellow]; propodeum black, but posterior teeth and valvulae dark brown [with two short yellow lines at apex]. First metasomal segment dark reddish-brown ventrally, black dorsally, with wide, yellow pre-apical band [red, partly somewhat brownish]; second segment black, with small, dull yellow spot on spiracle and rather narrow, yellow apical band [with large reddish spot on each side at base and narrow, yellow apical band]; third to sixth segments black [brownish]. Legs and wings as in R. plebeja.

Remarks: Our specimen generally agrees well with Van der Vecht's (1941) original description in structural characters, but distinctly differs in the arrangement of the ocelli and the sculpture on the propodeum. The marking pattern of our specimen is also different from that of the holotype. Van der Vecht (1941: 171) referred to another female specimen that "agrees with the holotype in shape and sculpture, but differs considerably in coloration." Detailed comparison based on more specimens is required to clarify whether a wide range of variation in structural and color characters occurs in this species or this "species" actually includes two or more very similar species.

\section{Nest}

A nest (Nest R-C-S) collected with a single female (not dissected for ovaries) by 

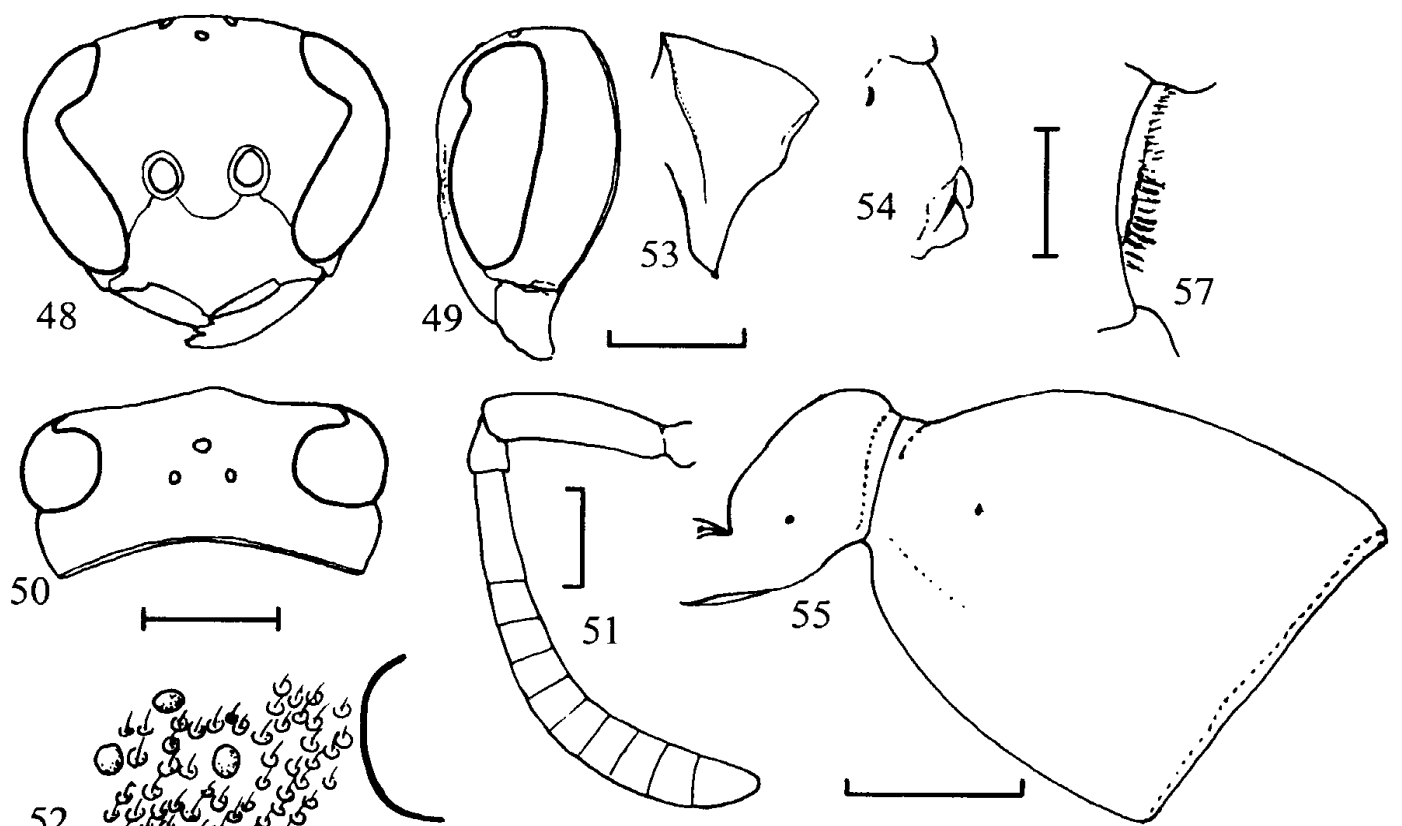

52
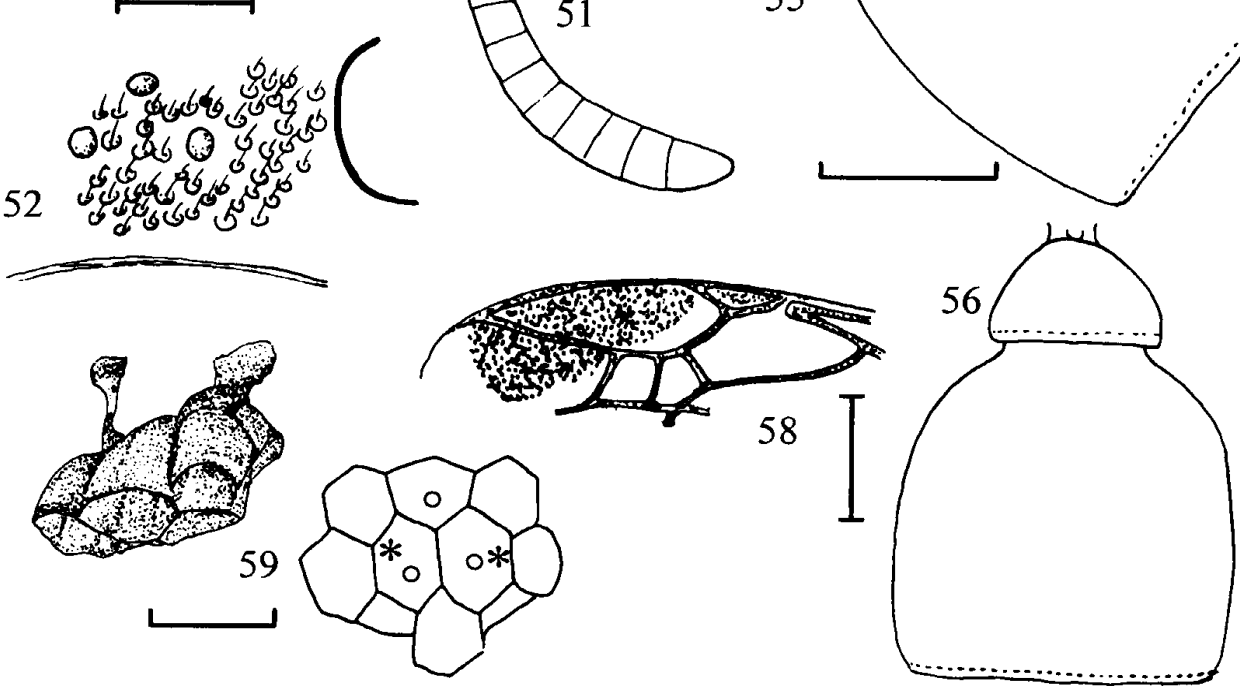

Figs 48-59. Ropalidia celebensis. 48-58, adult female; 59, nest. 48-50, head (48, frontal view; 49, lateral view; 50, dorsal view); 51, right antenna; 52, ocellar area; 53, pronotum, lateral view; 54 , propodeum, lateral view; 55-56, first two metasomal segments (55, lateral view; 56 , dorsal view); 57, basal part of second metasomal tergum, showing striae behind articulation; 58, anterodistal part of left forewing; 59, lateral view and view from cell opening of nest (showing outline of cell margins; without any immature individuals; open circle, "window" at cell bottom; asterisks, positions of pedicels). Scale lines: $48-50,53-56,58,1 \mathrm{~mm} ; 51-52,57,0.5 \mathrm{~mm}$; $59,5 \mathrm{~mm}$.

Dr. N. Tsurusaki was constructed on the underside of the trunk of a fallen tree (diameter about $70 \mathrm{~cm}$ ) about $1.2 \mathrm{~m}$ above the ground. The nest did not have any immature individuals and not all its cells were of full length, while the three central cells had transparent "windows" (Fig. 59). Other nest characters are as follows (see also Table 2): nest material consisting of short chips of plant fiber mixed with rather large amount of oral secretion; cell wall $0.05-0.1 \mathrm{~mm}$ thick, with short, narrow stripes of different colors (whitish gray, gray, pale brown to dark brown); cells arranged regularly, shallow peripheral cells with free margins rounded, but longer peripheral cells with hexagonal outline as in central cells; first (=petiolata) cell longest, $5.5 \mathrm{~mm}$ long and $3.0-3.8 \mathrm{~mm}$ in side-to-side diameter. Primary pedicel short 
$(1.4 \mathrm{~mm})$ and thick $(1.4 \mathrm{~mm})$, with thin core consisting mainly of chips of plant fiber, heavily coated with oral secretion; secondary pedicel long $(3.1 \mathrm{~mm})$ and thin, basal and distal thirds about $0.4 \mathrm{~mm}$ thick and consisting of mixture of short chips of plant fiber and oral secretion, median part about $0.3 \mathrm{~mm}$ thick and made purely of oral secretion.

\section{Ropalidia rufoplagiata (Cameron, 1905)}

Icaria rufoplagiata Cameron, 1905: 71, male, female, "Tjandi near Semarang"; Van der Vecht 1941: 167 [designation of lectotype].

Ropalidia gravelyi Dover and Rao, 1922: 244, female, "Kavalai, Cochin State, 1,000$3,000 \mathrm{ft} . "$ [India]. N. syn.

Ropalidia rufoplagiata: Van der Vecht 1941: 111, 165.

Ropalidia rufoplagiata var. gravelyi: Van der Vecht 1941: 104.

Ropalidia rufoplagiata gravelyi: Van der Vecht 1941: 168; 1962: 33; Das and Gupta 1984: 422; 1989: 137, 138, map 21.

Ropalidia rufoplagiata nursei Van der Vecht, 1941: 167, female, “India: ... Bombay Pres., Matheran" N. syn.

Ropalidia rufoplagiata rufoplagiata: Van der Vecht 1962: 32.

Ropalidia nursei: Richards 1978: 57.

Van der Vecht (1941) treated Ropalidia gravelyi first (p. 104) as a variety of $R$. rufoplagiata and then (p. 168) as a subspecies of $R$. rufoplagiata and he redescribed the marking pattern of the types of $R$. gravelyi. He also noted that specimens from Myanmar, Thailand, the Malay Peninsula, and Sumatra showed considerable variation in color pattern. The female from Bangalore, India, provided by Dr. R. Gadagkar has a brighter coloration than that of $R$. rufoplagiata gravelyi and better agrees with the "typical form" of $R$. rufoplagiata from Java. Our specimens from Lombok and Sumbawa run out at the first couplet of Das and Gupta's (1989) key to "subspecies" of $R$. rufoplagiata. Richards (1978) raised $R$. rufoplagiata nursei to species rank without mentioning any grounds for this treatment. Although the only name-bearing type that JK examined is that of Icaria rufoplagiata, he concluded, based on Van der Vecht (1941) and observations presented in this study, that those formally named forms are no more than color variations intergraded by transitional forms. Synonymies of $R$. gravelyi and $R$. rufoplagiata nursei under $R$. rufoplagiata are herewith proposed.

\section{Adult female}

The following description is based on the specimens listed in Table 1; for the structural characters, only diagnostic ones are mentioned.

Body length (head + mesosoma + first two metasomal segments) $7.0-8.5 \mathrm{~mm}(\mathrm{n}=$ 6); forewing length $6.2-6.8 \mathrm{~mm}(\mathrm{n}=6)$.

Vertex behind posterior ocelli nearly flat, but slightly sloping down to occipital carina near posterior margin (Fig. 61); head in dorsal view with lateral margins behind eyes only slightly convex; gena in profile (Fig. 61) about 0.9 times as wide as eye; distance between posterior ocelli about 0.65 times as long as distance between posterior ocellus and inner eye margin, and slightly more than twice as long as 

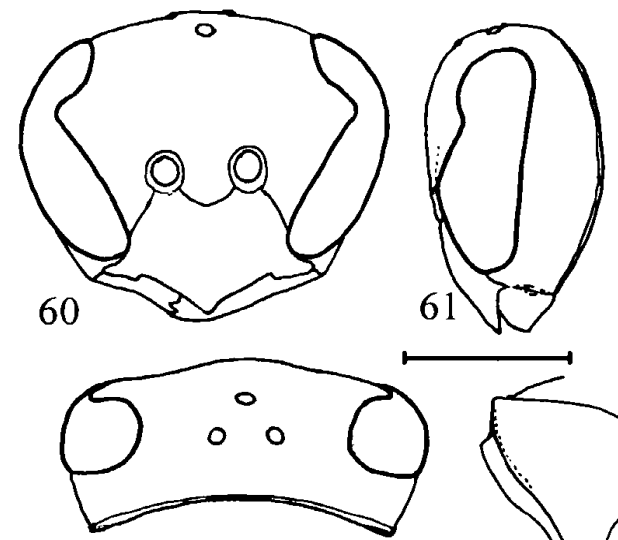

62
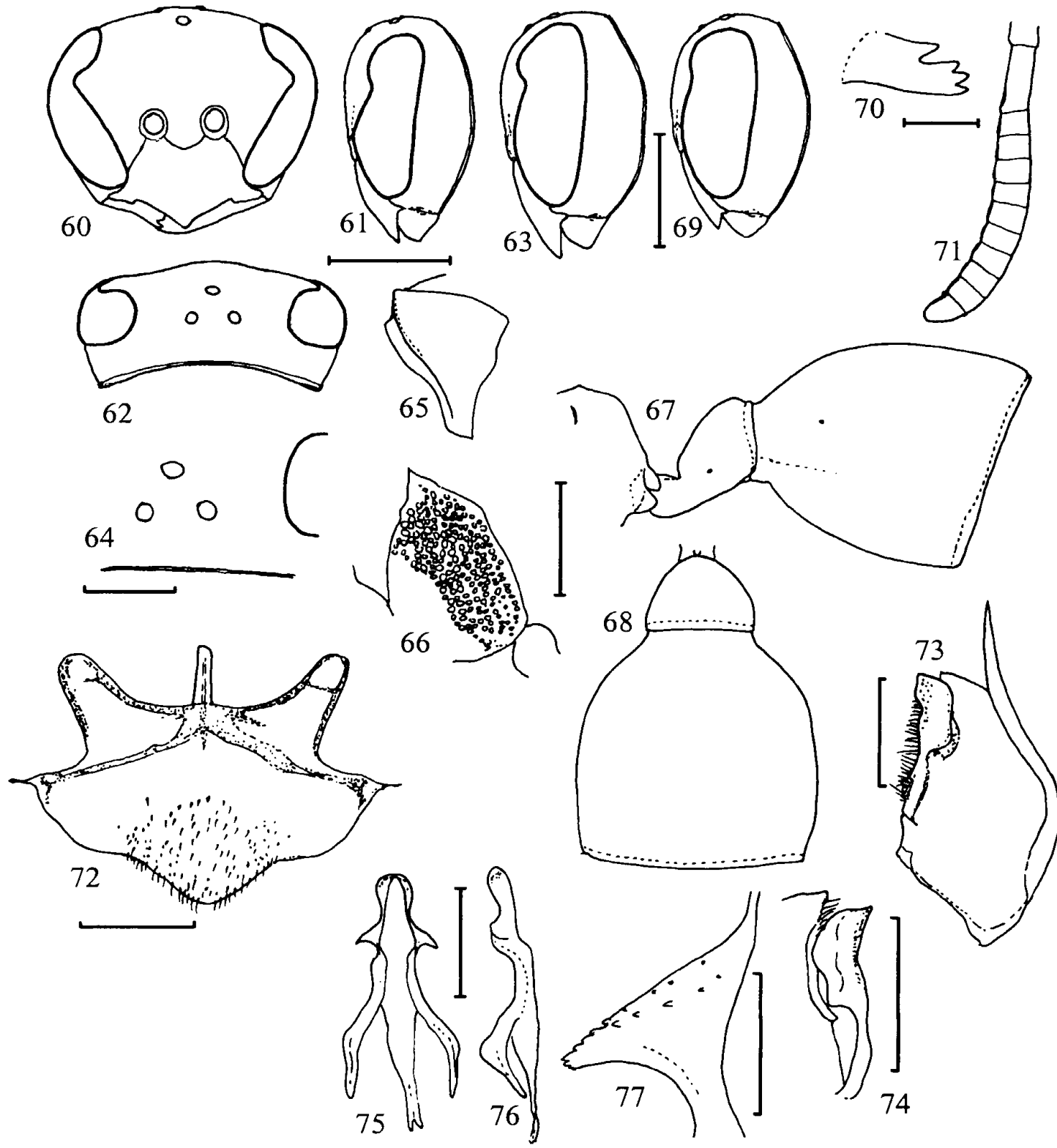

Figs 60-77. Ropalidia rufoplagiata. 60-62, 64-68, female from Lombok Island; 63, female from Bangalore, India; 69-77, male from Bangalore, India. 60-63, 69, head (60, frontal view; 61, 63, 69 , lateral view; 62 , dorsal view); 64 , ocellar area; 65 , pronotum, lateral view; 66 , mesepisternum, anterolateral view; 67, propodeum and first two metasomal segments, lateral view; 68, first two metasomal segments, dorsal view; 70, right mandible; 71, right antenna; 72, terminal sterna; 73, inner aspect of paramere with volsella and digitus; 74, volsella and digitus; 75-76, aedeagus (75, ventral view; 76 , lateral view); 77 , proximal part of penis valve, ventral view. Scale lines: $60-63,65-69,1 \mathrm{~mm}$; 64, 70-76, $0.5 \mathrm{~mm}$; 77, $0.1 \mathrm{~mm}$.

their diameter (Fig. 64). Ventral corner of pronotum (Fig. 65) truncate; border between punctured posterodorsal area and unpunctured anteroventral area of mesepisternum distinct (Fig. 66), sometimes marked with weak carina in ventral part; disc of metanotum broadly produced posteromedially; concavity on posterior 
face of propodeum rather deep and wide, its margins marked laterally by ridges; propodeum in profile (Fig. 67) with posterior surface broadly angled at level above mid-height of propodeum. First metasomal tergum in profile (Fig. 67) abruptly swollen dorsally at posterior end of basal slit, then dorsal margin weakly and broadly convex and broadly curved down to posterior lamella near apical margin; in dorsal view (Fig. 68) barely narrowed at posterior margin; posterior lamella depressed, wide and flat; posterior margin of articulation of second metasomal tergum weakly truncate medially, and laterally sharp-edged or slightly overhanging.

Head black; clypeus yellow, with central black spot, area above this spot reddish-brown; mandible reddish-brown, with basal yellow spot; spot at inner orbit and paired small spots between antennal sockets yellow; wide band along inner eye margin, large, irregular-shaped marking on frons, short transverse band behind posterior ocelli (often absent), and wide band on gena (often narrow, sometimes separated into large dorsal and small ventral spots) reddish-brown. Mesosoma black; pronotum reddish-brown (except black collar), with narrow yellow band along pronotal carina and sometimes with ill-defined black spot on each posteroventral corner; scutum sometimes reddish-brown laterally; tegula yellow, with semitransparent outer, brownish spot; mesepisternum sometimes with reddishbrown scrobal spot; disc of scutellum reddish-brown, sometimes with small black spot at posteromedian margin; metanotum yellow, sometimes with small, triangular, black spot at anteromedian margin. First metasomal segment black, with wide, yellow pre-apical band, but sometimes anterior face largely dark reddishbrown; second metasomal segment reddish-brown in basal half, gradually darkened posteriorly and black in front of apical yellow band; subsequent segments dark brown, with yellow apical band on each tergum. Legs reddish-brown; all coxae largely yellow, with basal parts black; trochanters and basal parts of femora partly black. Wings hyaline, yellowish along costal margin, with well defined, oval blackish cloud as in $R$. plebeja; veins brown; stigma yellowish-orange.

\section{Adult male}

Male characters that could be of phylogenetic importance, including genitalia, are described below based on a male specimen from Bangalore, India; for morphometric characters, the values for a female from Bangalore are given in brackets.

Head in frontal view relatively wider than in female, about 1.3 [1.15] times as wide as high; eye slightly more swollen laterally; inner eye margins more strongly converging ventrally than in female, their mutual distance at vertex about 1.5 [1.3] times as long as that at clypeus; clypeus less produced below, about 1.4 [1.3] times as wide as high; gena in profile (Fig. 69) proportionally slightly narrower than in female, about 0.85 [0.9] times as wide as eye; posterior ocelli more widely separated from each other, distance between them about 0.85 [0.65] times as long as distance from posterior ocellus to inner eye margin. Mandible (Fig. 70) with deep and wide emargination between dorsalmost and second teeth. Antennal scape short, thick, swollen medially, slightly less than 3 [nearly 3.5] times as long as wide; flagellum (Fig. 71) much less strongly swollen apically, widest at sixth or seventh article, then weakly narrowed apically; terminal article rounded apically, nearly 1.2 times as long as its own basal width; apical one-third of third article and fourth to terminal articles with longitudinal tyloids.

Terminal sterna and genitalia as in Figs 72-77. Parameral spine lacking hairs; 


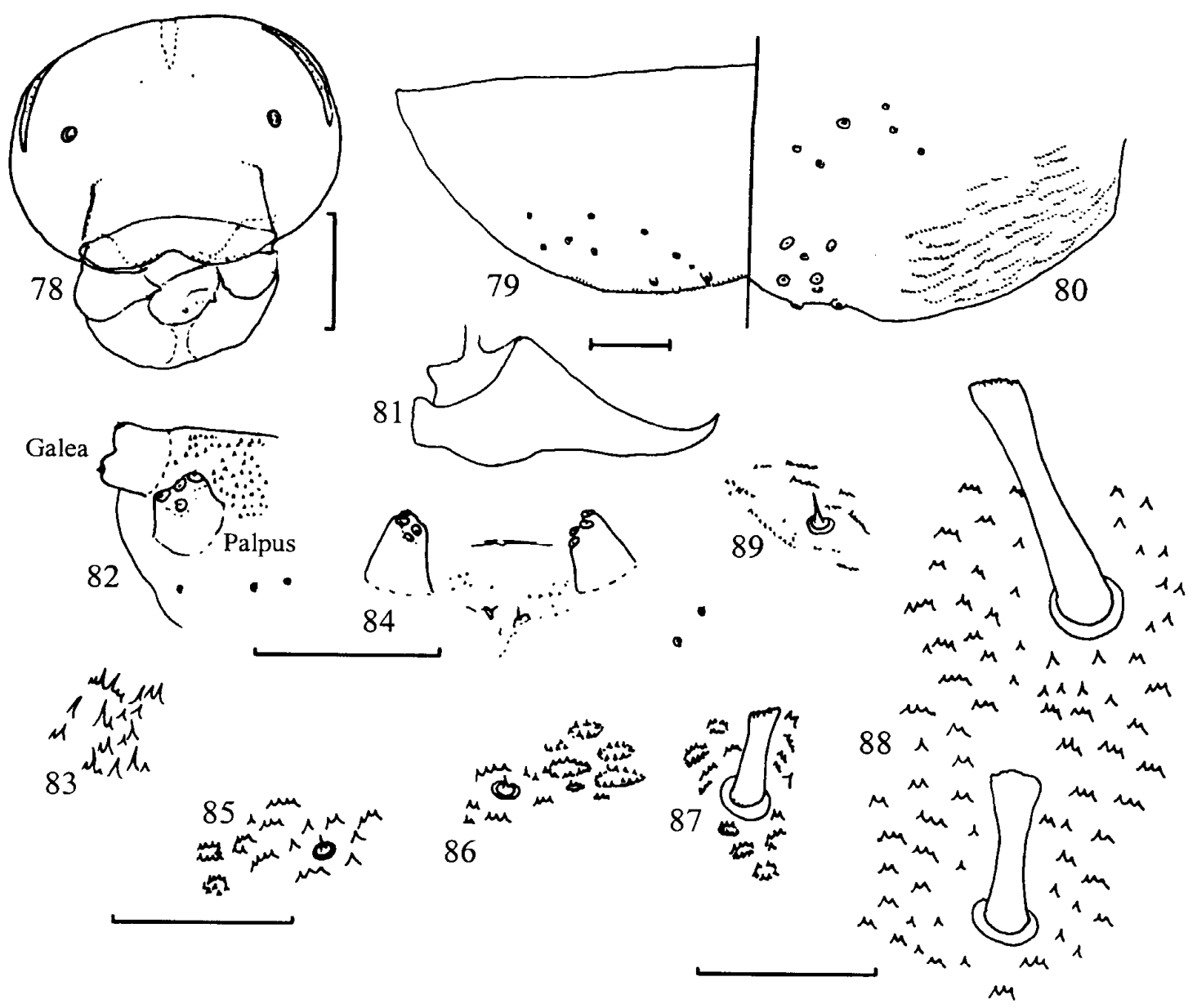

Figs 78-89. Mature larva of Ropalidia rufoplagiata. 78, head, frontal view; 79, labrum; 80 , palate; 81 , right mandible; 82 , apical part of left maxilla; 83 , spicules on upper surface of maxilla; 84, labial palpi and structures around them; 85-89, setae and spicules on body integument (85, venter of second thoracic segment; 86, anterior part of venter of third thoracic segment; 87 , posterior part of venter of third thoracic segment; 88, venter of first abdominal segment; 89 , dorsum of second thoracic segment). Scale lines: $78,0.5 \mathrm{~mm} ; 7982,84,0.1 \mathrm{~mm} ; 83$, $85-89,0.05 \mathrm{~mm}$.

Parameral Spine Index about 20. Volsella flattened, weakly spatulate (Fig. 74), and wide in inner aspect (Fig. 73). Penis valves short, slightly more than half as long as basal apodeme; in ventral view (Fig. 75) proximal parts strongly produced laterally into fin-like shape; in profile (Fig. 76) apical part weakly curved ventrally; proximal margin (Fig. 77) with weak teeth.

\section{Egg and larva}

Egg shape as in other social vespids, about $1.3 \mathrm{~mm}$ long and $0.45-0.5 \mathrm{~mm}$ in maximum diameter. Larval cranial width: $1.52-1.64 \mathrm{~mm}(\mathrm{n}=14)$ in fifth (=final), $1.12-1.24 \mathrm{~mm}(\mathrm{n}=6)$ in fourth, $0.82-0.92 \mathrm{~mm}(\mathrm{n}=4)$ in third, $0.65 \mathrm{~mm}(\mathrm{n}=1)$ in second, and $0.5 \mathrm{~mm}(\mathrm{n}=1)$ in first instar larvae.

Characters in final instar larva as follows: cranium dark brown; median longitudinal band in ventral half of frontal face, parietal band, and center of antenna 


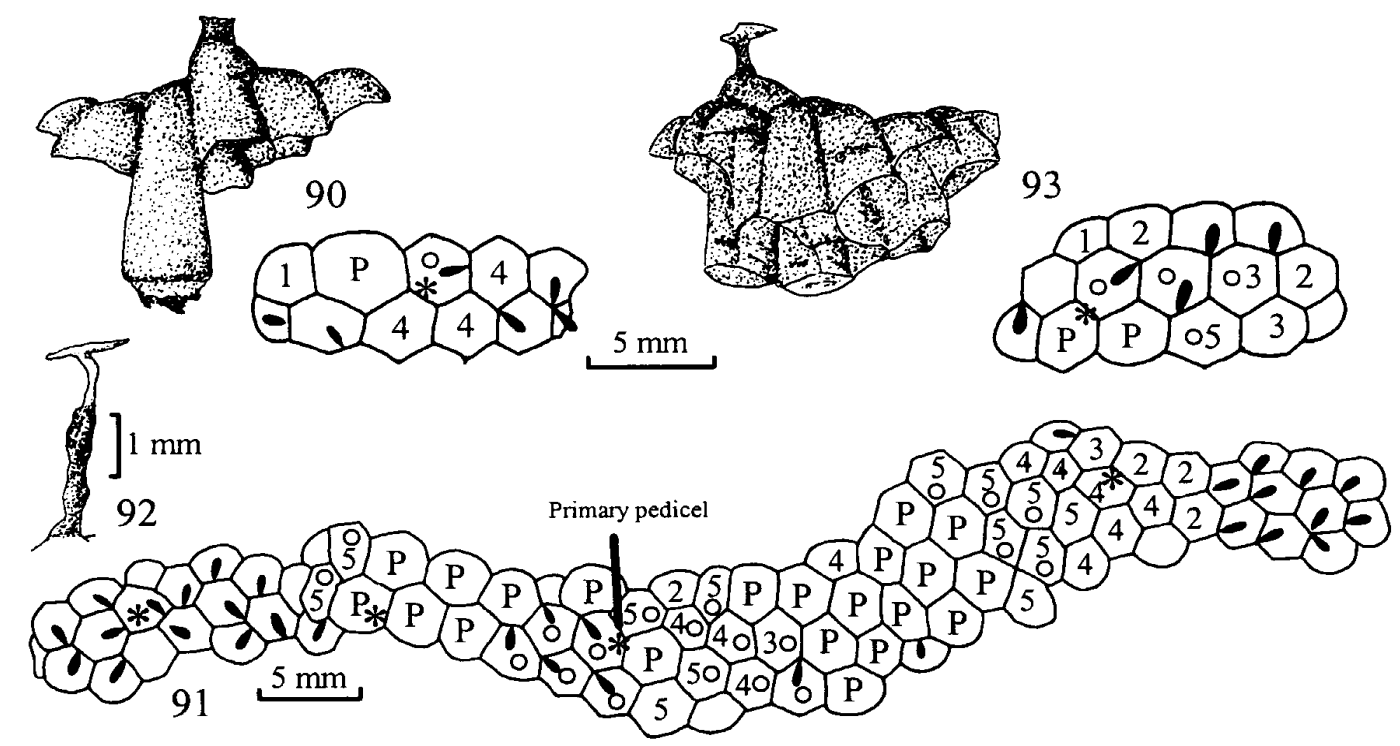

Figs 90-93. Nests of Ropalidia rufoplagiata. 90 (Nest R-21), 93 (R-40), lateral view and view from cell opening (showing outlines of cell margins, deposition of immature stages, position of pedicel, and presence of "window" at bottom of cell); 91 (R-23), view from cell opening; 92 (R-23), secretion pedicel. Solid tear-drop marks, eggs; numerals, instar stages of larvae; "P", pupa, cell bottom with "window"; open circle, "window" at bottom of non-pupal cell; asterisks, positions of pedicels.

pale whitish-brown; clypeus sometimes paler; mouthparts brown to dark brown, but labrum, upper part of maxilla, and median part of postmentum unpigmented; body unpigmented, but venters of thoracic segments largely dark brown. Structure (Figs 78-89) as in R. plebeja, but mandible (Fig. 81) without spicules; spicules on upper surface of maxilla (Fig. 83) often contiguous; paired setae behind labial palpi (Fig. 84) short, with weakly raised sockets; area between labial palpi with scattered, minute spicules. Venter of $\mathrm{T} 1$ with scattered, minute setae but lacking spicules; anterior half of T2 venter bare, posterior half with scattered minute setae and dense, minutely dentate spicules (Fig. 85); T3 venter covered with dense, minute spicules, often arranged in circle (Figs 86-87), setae in anterior half scattered and minute, those in posterior half thick and minutely dentate apically; spicules and setae on A1 venter and subsequent venters and on dorsums of all body segments as in R. plebeja.

\section{Nests and colony populations}

Nest R-21 (Fig. 90) collected at Pusak, Lombok Island, was constructed under the eaves of a small gazebo hut, about $2 \mathrm{~m}$ above the ground. The nest had a single, short and thick pedicel (Table 2) with a central core made mainly of plant fiber chips and surrounded by several layers of thin film of oral secretion; the cells were arranged regularly in two rows. A single female was collected with the nest; the female was inseminated and had developed ovaries with four mature oocytes.

Another nest collected at Pusak (Nest R-23) was constructed on a vertical wooden plate under eaves at about $2.5 \mathrm{~m}$ above the ground. The comb was parallel to the substrate, thus the cell axes were horizontal. When we collected the nest by 
scraping it off with an insect net, two of four pedicels (the primary and one of the secondary pedicels) remained on the substrate together with the basal parts of the cells to which the pedicels had been attached. In a further attempt to collect these pedicels we broke and lost them. The comb shape (Fig. 91) was rather irregular, but the cells were arranged more or less regularly, without any signs that independently initiated multiple combs had been fused. The two pedicels that remained intact were slender; the part corresponding to the cell base was made of a mixture of plant fiber chips and oral secretion, while the part attached to the substrate was of purely oral secretion (Fig. 92). Four adult females were on the nest when it was collected. One of the females was uninseminated and had undeveloped ovaries; judging from her rather soft cuticle, this female could have emerged at most a few days before collection. All of the other three females were inseminated; one had well developed ovaries with several mature oocytes, another had less developed ovaries but still a few mature oocytes, and the last one had ovaries showing slight development of oocytes.

The last nest (R-40; Fig. 93) was collected with a single female at Batudulang, Sumbawa Island; the nest was built under eaves about $2.2 \mathrm{~m}$ above the ground. The comb was suspended from the horizontal surface of a wooden board by a single subterminal pedicel, which had a central core made of plant fiber chips mixed with oral secretion and was rather thickly coated with oral secretion. The female was inseminated and had developed ovaries (with three mature oocytes).

Other general nest characters are as follows: nest material consisting of short chips of plant fiber mixed with rather large amount of oral secretion; comb color pale brown (Nest R-21, R-40) or grayish-brown (R-23), with narrow darker stripes. Shallow peripheral cells with their free margins rounded, but longer peripheral cells hexagonal like central cells; mean length and side-to-side diameter of pupal cells $7.3 \mathrm{~mm}$ (range $6.2-8.5 \mathrm{~mm}, \mathrm{n}=13$ ) and $3.0 \mathrm{~mm}$ (range $2.6-3.4 \mathrm{~mm}, \mathrm{n}=13$ ), respectively; cells with "windows" and containing eggs or younger larvae distinctly shorter than pupal cells. Cocoon caps brown, usually with blots of plant fiber chips, nearly flat at level of rim of cell or slightly inside rim of cell, or domed and produced beyond rim of cell by $1-2 \mathrm{~mm}$.

\section{Key to Species of the R. plebeja Group}

The following key gives the diagnostic characters and a summary of the distributional records for the species of the $R$. plebeja group. We have not examined any specimens of $R$. andamanensis, and the characters for this species are extracted from the original description (Das and Gupta 1989). Unless the sexes are specified, the characters given in the key should be applicable to both sexes; however, the male is not known for $R$. celebensis and $R$. andamanensis.

1. Pronotal carina strongly produced anteriorly into thin lamella (Figs 98, 105). Vertex behind ocelli in profile with outline slightly swollen dorsally toward occipital carina (Figs 94, 103, 107). Border between punctured posterodorsal area and unpunctured anteroventral area of mesepisternum ill-defined (Fig. 99). Terminal article of male antenna long, distinctly more than 1.5 times as long as its own basal width (Fig. 102) .2 


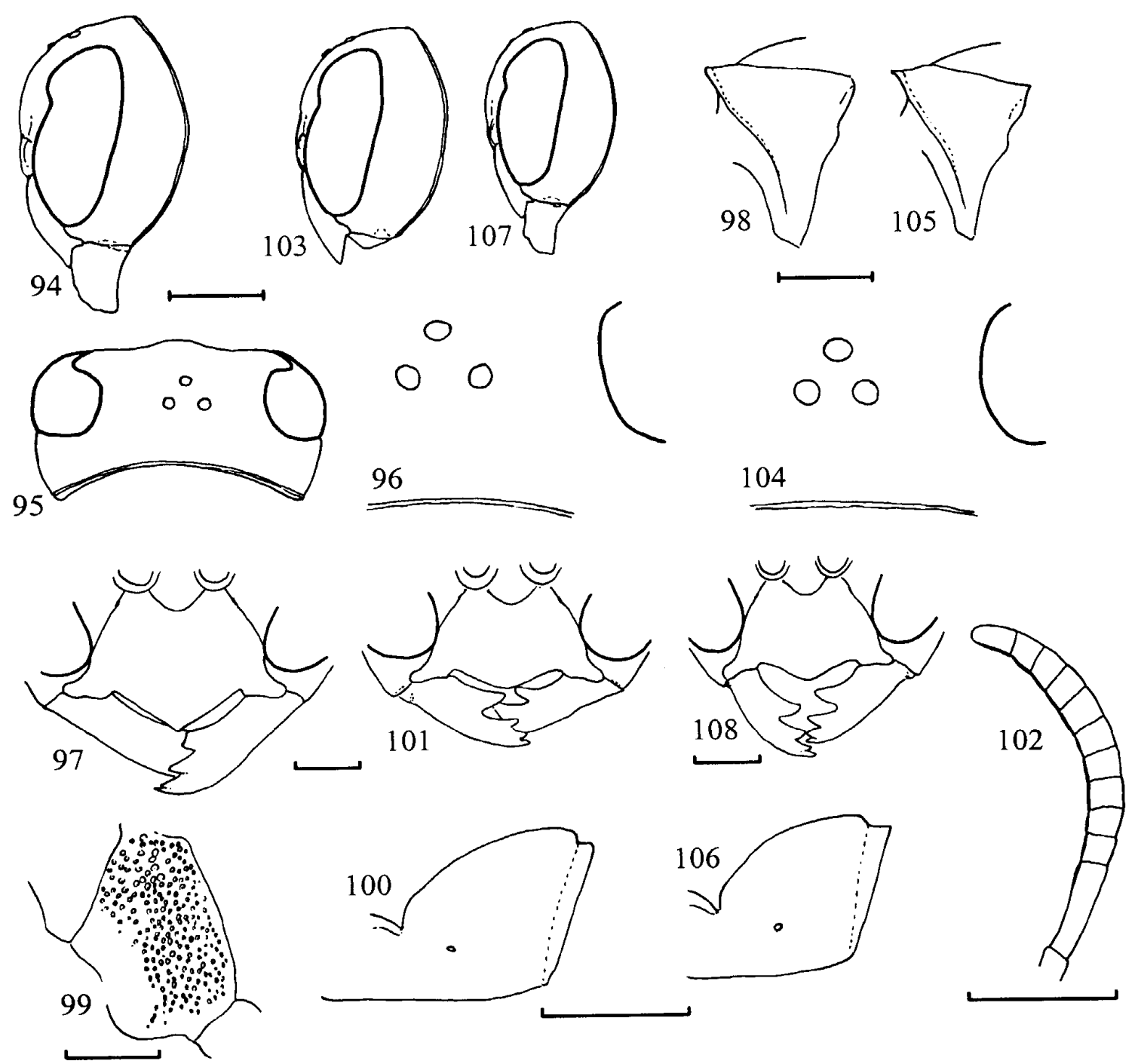

Figs 94-108. Characters of Ropalidia turneri (94-102) and R. cristata (103-108). 94-100, 103-104, female; 101-102, 107-108, male. 94-95, 103, 107, head (94, 103, 107, lateral view; 95, dorsal view); 96, 104, ocellar area; 97, 101, 108, ventral part of head, frontal view; 98, 105, pronotum, lateral view; 99, mesepisternum, anterolateral view; 100, 106, first metasomal tergum, lateral view; 102, right antenna. Scale lines: 94-95, 98-100, 102-103, 105-107, 1 mm; 96-97, 101, $104,108,0.5 \mathrm{~mm}$.

Pronotal carina raised into thin lamella, but hardly produced at all anteriorly (Figs $6,53,65$ ). Vertex behind posterior ocelli nearly flat or very weakly sloping down to occipital carina; in profile its outline not swollen dorsally toward posterior margin (Figs 2, 12, 49, 61, 63, 69). Border between punctured posterodorsal and unpunctured anteroventral areas of mesepisternum well-defined (Fig. 66), sometimes marked by weak carina in ventral part. Terminal article of male antenna relatively short, less than 1.5 times as long as its own basal width (Figs 16, 71)

2. Distance between posterior ocelli 1.7 times or more as long as their diameter (Fig. 96); space between posterior ocelli with few punctures. Gena in profile 
smoothly widening ventrally to level of middle of eye, then smoothly narrowing toward mandibular base (Fig. 94); occipital carina broadly and regularly curved. Posterior lamella of first metasomal tergum narrow, strongly depressed; in profile length of lamella nearly same as depth of depression (Fig. 100) R. turneri

Distributional records: Northeastern part of Queensland, Australia (Richards 1978; Kojima 1999b, c).

- Distance between posterior ocelli less than 1.5 times their diameter in female (Fig. 104); space between posterior ocelli hardly punctured. Gena in profile widening ventrally to level of about one-third from top of eye, then posterior margin of gena (or occipital carina) running down nearly parallel to posterior margin of eye and recurved anteriorly near base of mandible (Fig. 103). Posterior lamella of first metasomal tergum wide and not strongly depressed; in profile length of lamella distinctly longer than depth of depression (Fig. 106).

Distributional records: Southeastern part of Papua New Guinea (Kojima 1989;

Spradbery and Kojima 1989; Kojima 2001).

3. First metasomal tergum in profile strongly swollen dorsally in posterior half; posterior lamella barely depressed and not flattened (Figs 8,55$)$

- First metasomal tergum in profile relatively weakly swollen dorsally in posterior half; posterior lamella depressed and flattened (Fig. 67)

4. First metasomal tergum in profile strongly swollen dorsally just behind basal slit, with dorsal surface relatively broadly curving down toward posterior margin from highest point of tergum (Fig. 8), in dorsal view, distinctly narrowing posteriorly near posterior margin (Fig. 9). In female, distance between posterior ocelli less than 3 times diameter of posterior ocellus (Fig. 5); gena in profile less than 0.9 times as wide as eye (Fig. 2) R. plebeja Distributional records: North Sulawesi (Gorontalo: Saussure 1862), Central Sulawesi (Lake Paso: Van der Vecht 1962), South Sulawesi (present study).

- First metasomal tergum in profile less strongly swollen dorsally at posterior margin of basal slit, with dorsal face broadly and weakly curving down toward posterior margin from highest point of tergum (Fig. 55), in dorsal view barely narrowing posteriorly (Fig. 56). In female, distance between posterior ocelli more than 3 times their diameter (Fig. 52); gena in profile nearly as wide as eye (Fig. 49) $R$. celebensis

Distributional records: South Sulawesi (Van der Vecht 1941; present study).

5. Median concavity of propodeum deep and wide, with distinct lateral edges. Metanotum slightly produced posteriorly in middle R. rufoplagiata [Synonyms: Ropalidia gravelyi Dover and Rao; $R$. rufoplagiata nursei Van der Vecht]

Distributional records: India (Utter Pradesh, Maharashtra, Karnataka, Kerala, Andaman Islands), Myanmar, Thailand, Malay Peninsula, Sumatra, Bangka, Java, Lombok, Sumbawa (Cameron 1905; Dover and Rao 1922; Van der Vecht 1941, 1962; Das and Gupta 1984, 1989; present study).

- Median concavity of propodeum shallow and narrow, without distinct lateral edges. Metanotum not produced posteriorly in middle R. andamanensis Distributional record: Andaman Islands (Das and Gupta 1989). 


\section{Discussion}

Wenzel (1987) examined colony populations of a large number of nests of Ropalidia formosa (Saussure, 1853) in Madagascar and assumed that this species has a nearly solitary life habit. The mean number of cells per nest that produced adults (that is, the nests with "windows") in R. plebeja (11.0 cells for active nests, and 13.2 cells for abandoned nests) is comparable with that for $R$. formosa (6.0-22.5 for five populations). Both the numbers of fewest cells at the first adult emergence (the sexes were not determined) and at male emergence in $R$. plebeja (four and fewer than ten cells, respectively) are smaller than those in $R$. formosa (eight and 20 cells, respectively). Not only the small nest size, but also the results of dissections and measurement of the body size of the attending females and brood composition suggest that $R$. plebeja also has a nearly solitary life habit. That is, emerging females probably leave their natal nests to initiate their own nests after helping their mothers for a brief time.

Ropalidia celebensis may similarly have a nearly solitary life habit, but the observations reported here on three colonies of $R$. rufoplagiata indicate that wasps of this latter species may alternate a nearly solitary life habit and social life habit with many females on a nest in the course of a colony's history. Sinha et al. (1993) found that a permanent reproductive division of labor is absent in $R$. rufoplagiata, but all the older females are egg-layers and younger females are mainly involved in foraging. A further detailed comparison of social life with reference to phylogenetic relationships is required in order to clarify whether such an age polyethism in reproductive division of labor is primitive or secondarily derived in the genus Ropalidia. On the other hand, the unusually small colony size and nearly solitary life habit of $R$. plebeja could represent secondary reduction rather than retention of a primitive state.

Notable nest characteristics observed in $R$. plebeja, $R$. celebensis, and $R$. rufoplagiata are that (1) the cells with "windows" and having no brood or only younger immatures (eggs or earlier instar larva) are distinctly shorter than the pupal cells, and (2) the cell walls usually had no distinct stripes indicating different origins of nest material, but instead, each extension of a cell wall seemed to be made with a mixture of plant material of different origins. These findings suggest that the wasps recycle nest material within a comb or even transport nest material of the original nest to construct new combs as observed in R. turneri (Kojima unpublished).

Besides having a first metasomal tergum that is barely petiolate basally but abruptly swollen dorsally at the posterior end of the basal slit, several additional characters discussed below are also good candidates for defining the $R$. plebeja group or for linking this group to another species group in the genus, although Das and Gupta (1989) did not mention any of them in their description of $R$. andamanensis. In all five species examined in the present study, the vertex behind the posterior ocelli is flat or very slightly sloping down to the occipital carina. Similar states are found in $R$. catharinae (Cameron, 1913) from New Guinea, a species of uncertain identity from Madagascar, $R$. pilosa (Smith, 1858), and $R$. binghami Van der Vecht, 1941 (Kojima unpublished). However, there are no other characters suggesting close relationships of any of these four species with the $R$. plebeja group.

Truncate or obliquely cut off ventral corners of the pronotum are also found in 
all five species examined in this study. Similar conditions are found in two closely allied Oceanian species, $R$. gracilis (Smith, 1859) and $R$. gracilenta Richards, 1978 ( $R$. gracilis group in Kojima 2001), while in other species of Ropalidia the ventral corners of the pronotum are pointed. This character may be a synapomorphy for the $R$. plebeja group plus $R$. gracilis group.

In the Vespidae, the eyes in the male are usually more strongly swollen laterally than in the female, and the gena is proportionally (in terms of gena/eye ratio) distinctly narrower in the male than in the female. In the four species in the $R$. plebeja group, the males of which are known, and both species in the $R$. gracilis group, the sexual dimorphism in these characters is weak or the gena is even proportionally wider in the male than in the female (see also Kojima 2001). These characters also suggest a close affinity of the $R$. plebeja group and $R$. gracilis group.

The mandibles of males of $R$. plebeja, $R$. rufoplagiata, $R$. turneri, and $R$. cristata are very peculiar in the genus Ropalidia as well as in the Polistinae as a whole. This could also be a robust character supporting the monophyly of the $R$. plebeja group, although the males of $R$. celebensis and $R$. andamanensis are not known.

The strong and apically minutely dentate setae on the venters of the larval third thoracic and first abdominal segments observed in $R$. plebeja and $R$. rufoplagiata are also found in $R$. turneri (Kojima 1998; however, Richards (1978: 65) mentioned in a key to larvae that the "1st abdominal sternite [is] bare") and $R$. cristata (Yamane and Okazawa 1981; Kojima 1989). Similar setae occur on the venters of the second and third thoracic and first abdominal segments in $R$. stigma (Smith, 1858) (Kojima and Yamane 1984). The $R$. stigma group includes $R$. mathematica (Smith, 1860 ) and $R$. rufocollaris (Cameron, 1900), for the larvae of which were described as not having such strong setae on the body integument (Kojima and Yamane 1984; Kojima 1998).

Finally, besides the nests of the three species described herein, secondary pedicels made mainly of oral secretion are also known in the nests of $R$. cristata (Spradbery and Kojima 1989) and R. turneri (Yokoyama and Kojima unpublished). In Ropalidia, and possibly in the social Vespidae as a whole, such secretion-built pedicels are known only in these five species in the $R$. plebeja group.

The monophyly of the $R$. plebeja group seems to be clear, but its distributional pattern is puzzling. Ropalidia rufoplagiata is distributed from India in the west, through Myanmar, the Malay Peninsula, Sumatra, and Java, to Sumbawa in the east. Ropalidia plebeja and $R$. celebensis have been recorded only from Sulawesi; $R$. cristata has been known from only the eastern part of New Guinea and $R$. turneri is distributed in the northeastern part of Australia's Queensland. Thus the $R$. plebeja group shows a disjunct distributional pattern, with no collection records of any species belonging to it in the eastern part of the Lesser Sunda Islands, the Molucca Islands, or the western part of New Guinea. Further intensive research including that on museum collections could shed light on the biogeography of the $R$. plebeja group.

\section{Acknowledgments}

The present study was carried out with the permission of the Lembaga Ilmu 
Pengetahuan Indonesia (LIPI) and was supported by Grants-in-Aid from the Japan Society for the Promotion of Science (nos 11691161 and 11833001). Our thanks are owed to two anonymous reviewers for valuable suggestions on the manuscript and to $\mathrm{N}$. Tsurusaki for collecting the colony of $R$. celebensis, and JK also thanks C. van Achterberg and J. Cardale for their help with research in the Nationaal Natuurhistorisch Museum and the Australian National Insect Collection, respectively.

\section{References}

Cameron, P. 1905. On the Malay fossorial Hymenoptera and Vespidae of the Museum of the R. Zool. Soc. "Natura Artis Magistra" at Amsterdam. Tijdschrift voor Entomologie 48: 48-78.

Charnley, H. W. 1973. The value of the propodeal orifice and the phallic capsule in vespid taxonomy (Hymenoptera, Vespidae). Bulletin of the Buffalo Society of Natural Sciences 26: 1-79.

Das, B. P. and Guputa, V. K. 1984 [dated 1983]. A catalogue of the families Stenogastridae and Vespidae from the Indian subregion (Hymenoptera: Vespidae). Oriental Insects 17: 395464.

Das, B. P. and Gupta, V. K. 1989. The social wasps of India and the adjacent countries. Oriental Insects Monograph 11: 1-292.

Dover, C. and Rao, H. S. 1922. A note on the diplopterous wasps in the collection of the Indian Museum. Journal of the Asiatic Society of Bengal (New Series) 18: 235-249.

Kojima, J. 1989. A new polistine species of Ropalidia (Hymenoptera, Vespidae) from Papua New Guinea. Japanese Journal of Entomology 57: 143-147.

Kojima, J. 1996. Meconium egestion by larvae of Ropalidia Guérin (Hymenoptera: Vespidae) without adult aid, with a note on the evolution of meconium extraction behavior in the tribe Ropalidiini. Australian Journal of Entomology 35: 73-75.

Kojima, J. 1997. Abandonment of the subgeneric concept in the Old World polistine genus Ropalidia Guérin-Méneville, 1831 (Insecta: Hymenoptera: Vespidae). Natural History Bulletin of Ibaraki University (1): 93-106.

Kojima, J. 1998. Larvae of social wasps (Insecta: Hymenoptera; Vespidae). Natural History Bulletin of Ibaraki University (2): 7-227.

Kojima, J. 1999a. Male genitalia and antennae in an Old World paper wasp genus Ropalidia Guérin-Méneville, 1831 (Insecta: Hymenoptera; Vespidae, Polistinae). Natural History Bulletin of Ibaraki University (3): 51-68.

Kojima, J. 1999b. Taxonomic notes on Australian Ropalidia Guérin-Méneville, 1831 (Hymenoptera: Vespidae, Polistinae). Entomological Science 2: 367-377.

Kojima, J. 1999c. A key to species and notes on distribution of the polistine genus Ropalidia Guérin-Méneville, 1831 (Hymenoptera: Vespidae, Polistinae) in Australia. Entomological Science 2: 379-390.

Kojima, J. 2001. Ropalidia wasps (Insecta: Hymenoptera; Vespidae, Polistinae) in New Guinea and its adjacent islands (first part). Natural History Bulletin of Ibaraki University (5): 31-60.

Kojima, J. and Achterberg, C. van 1997. List of the primary types of social wasps (Hymenoptera: Vespidae) deposited in the Nationaal Natuurhistorisch Museum, Leiden, and the Zoölogisch Museum, Amsterdam. Zoologische Mededelingen 71: 157-169.

Kojima, J. and Carpenter, J. M. 1997. Catalog of species in the polistine tribe Ropalidiini (Hymenoptera: Vespidae). American Museum Novitates (3199): 1-96. 
Kojima, J. and Yamane, Sk. 1984. Systematic study of the mature larvae of Oriental polistine wasps (Hymenoptera: Vespidae) (I) species of Ropalidia and Polistes from Sumatra and Java Islands. Reports of the Faculty of Science, Kagoshima University (Earth Sciences and Biology) (17): 103-127.

Richards, O. W. 1978. The Australian social wasps (Hymenoptera: Vespidae). Australian Journal of Zoology, Supplementary Series (61): 1-132.

Saussure, H. de 1862. Sur divers Vespides asiatiques et africains du Musée de Leyden. Stettiner Entomologische Zeitung 23: 129-141.

Sinha, A., Premnath, S., Chandrashekara, K. and Gadagkar, R. 1993. Ropalidia rufoplagiata: a polistine wasp society probably lacking permanent reproductive division of labor. Insectes Sociaux 40: 69-86.

Spradbery, J. P. and Kojima, J. 1989. Nest descriptions and colony populations of eleven species of Ropalidia (Hymenoptera, Vespidae) in New Guinea. Japanese Journal of Entomology 57: 632-653.

Van der Vecht, J. 1941. The Indo-Australian species of the genus Ropalidia (=Icaria) (Hym., Vespidae) (first part). Treubia 18: 103-190.

Van der Vecht, J. 1962. The Indo-Australian species of the genus Ropalidia (Icaria) (Hymenoptera, Vespidae) (second part). Zoologische Verhandelingen (57): 1-72, 8 pls.

Wenzel, J. W. 1987. Ropalidia formosa, a nearly solitary paper wasp from Madagascar (Hymenoptera: Vespidae). Journal of the Kansas Entomological Society 60: 549-556.

Wenzel, J. W. 1998. A generic key to the nests of hornets, yellowjackets, and paper wasps worldwide (Vespidae: Vespinae, Polistinae). American Museum Novitates (3224): 1-39.

Yamane, Sk. and Okazawa, T. 1981. Mature larvae of some polistine wasps from Papua New Guinea and Fiji, with notes on larval characters of the Old World and Oceanian Polistinae (Hymenoptera: Vespidae). Reports of the Faculty of Science, Kagoshima University (Earth Sciences and Biology) (14): 65-75. 